\title{
Microbial Transglutaminase in Noodle and Pasta Processing
}

\section{Gharibzahedi, Seyed Mohammad Taghi; Yousefi, Shima; Chronakis, loannis S.}

\section{Published in:}

Critical Reviews in Food Science and Nutrition

Link to article, DOI:

10.1080/10408398.2017.1367643

Publication date:

2018

Document Version

Peer reviewed version

Link back to DTU Orbit

Citation (APA):

Gharibzahedi, S. M. T., Yousefi, S., \& Chronakis, I. S. (2018). Microbial Transglutaminase in Noodle and Pasta Processing. Critical Reviews in Food Science and Nutrition, 59(2), 313-327.

https://doi.org/10.1080/10408398.2017.1367643

\section{General rights}

Copyright and moral rights for the publications made accessible in the public portal are retained by the authors and/or other copyright owners and it is a condition of accessing publications that users recognise and abide by the legal requirements associated with these rights.

- Users may download and print one copy of any publication from the public portal for the purpose of private study or research.

- You may not further distribute the material or use it for any profit-making activity or commercial gain

- You may freely distribute the URL identifying the publication in the public portal

If you believe that this document breaches copyright please contact us providing details, and we will remove access to the work immediately and investigate your claim. 


\section{Critical Reviews in Food Science and Nutrition}

\section{Microbial Transglutaminase in Noodle and Pasta Processing}

\section{Seyed Mohammad Taghi Gharibzahedi, Shima Yousefi \& Ioannis S. Chronakis}

To cite this article: Seyed Mohammad Taghi Gharibzahedi, Shima Yousefi \& Ioannis S. Chronakis (2017): Microbial Transglutaminase in Noodle and Pasta Processing, Critical Reviews in Food Science and Nutrition, DOI: 10.1080/10408398.2017.1367643

To link to this article: http://dx.doi.org/10.1080/10408398.2017.1367643

Accepted author version posted online: 31 Aug 2017.

Submit your article to this journal ๘

Џ Article views: 16

Q View related articles ¿

View Crossmark data $₫$ 
Microbial Transglutaminase in Noodle and Pasta Processing

Seyed Mohammad Taghi Gharibzahedi ${ }^{a}{ }^{*}$, Shima Yousefi ${ }^{b}$, Ioannis S. Chronakis ${ }^{c}$

${ }^{a}$ Young Researchers and Elites Club, Science and Research Branch, Islamic Azad University, Tehran 14778-93855, Iran

${ }^{\mathrm{b}}$ College of Food Science and Technology, Science and Research Branch, Islamic Azad University, P.O. Box 1476714171, Tehran, Iran

${ }^{c}$ Nano-Bio Science Research Group, DTU-Food, Technical University of Denmark, Soltofts Plads, B 227, 2800 Kgs. Lyngby, Denmark

*Corresponding author. Email: smt.gharibzahedi@gmail.com; Fax \& Tel: +98 2144861799

\begin{abstract}
Nowadays, there is an aggressive rate in consumption of noodles and pasta products throughout the world. Consumer acceptability and preference of these functional products can be promoted by the discovery of novel knowledge to improve their formulation and quality. The development of fortified-formulations for noodles and pasta products based on microbial transglutaminase (MTGase) can guarantee the shelf life extension with minimum quality losses. The current review focuses on recent trends and future prospects of MTGase utilization in the structural matrix of noodles and pasta products and represents the quality changes of cooking loss, texture, microstructure, color and sensory attributes of the MTGase-incorporated products. Digestibility, nutritional and health aspects of the MTGase-enriched formulations are also reviewed with a vision toward physical functions and safety outcomes of MTGases isolated from new microbial sources. The high potential of MTGase in developing commercial noodles and pasta products is
\end{abstract}




\section{ACCEPTED MANUSCRIPT}

successfully demonstrated. MTGase by modifying the crystallinity or molecular structure via covalent crosslinks between protein molecules strengthens the doughs stability and the textural characteristics of final products with the low- or high-protein flour. Compared with the control samples, the MTGase-supplemented products indicate slower digestion rates and better sensory and cooking properties without any remarkable color instability.

Keywords: Transglutaminase, Noodle dough, Spaghetti, Gluten-free, Quality, Texture 


\section{ACCEPTED MANUSCRIPT}

\section{INTRODUCTION}

In recent years, noodle and pasta products have considered as one of the most important staple foods for a large part of the world's population. Based on the released data by world instant noodle association in 2015, China/Hong Kong, Indonesia, Japan, Viet Nam and the United States were the largest consumers of noodles (69.7\% of total world consumption) (WINA, 2016a). On the other hand, Italy, the United States, Turkey, Brazil, Russia and Iran respectively were the major producers of pasta $(\sim 9,410,078$ tons) in 2015 (UNAFPA, 2016). Increasing the production and consumption rate of these strategic products can be attributed to the simplicity in transportation, cooking, preparation, production mechanization and infrastructure development (Li et al., 2014b).

In parallel with further development and diversity of these wheat-based functional products in the industrial scale, use of particular reinforcing compounds (e.g., natural and chemical additives) and pre-treatments (e.g., hydrothermal, fermentation, and enzymatic) could substantially improve the dough rheological characteristics and the physicochemical quality of final products (Gulia et al., 2014). Meanwhile, the enzymatic treatments (with lipases, amylases, oxidoreductase and transglutaminase (TGase)) as sustainable and revolutionary bio-processing solutions can deliver whole-grain cereal products with attractive sensory attributes and a decreased quantity of chemical agents (Niu et al., 2017).

TGase is extensively found in many mammalian, invertebrate and plant tissues and microbial cells (Kieliszek and Misiewicz, 2014). This enzyme induces covalent crosslinks between two amino-acid residues of glutamine and lysine by the catalysis reaction of acyl transfer, without any limiting effect on the bioavailability of essential amino acid of lysine (Seguro et al., 1996; Li 


\section{ACCEPTED MANUSCRIPT}

et al., 2014b). Seguro et al. (1996) after feeding TGase-treated proteins to rats demonstrated that lysine would be available for protein metabolism. Raczynski et al. (1975) from in vivo studies on rats found that the crosslinked structure ( $\varepsilon$-( $\gamma$-L-glutamyl)-L-[14C]lysine) by TGase can be absorbed in the small intestine and that the $14 \mathrm{C}$ of the lysine was incorporated into plasma proteins. Fink and Folk (1981) also realized that $\varepsilon$-( $\gamma$-glutamyl)-Lysine isopeptides obtained by TGase function are an accessible substrate for the $\gamma$-glutamyl aminocyclotransferase (E.C. 2.3.2.4) of kidneys. Therefore, TGase by polymerizing proteins (e.g., gliadins and highmolecular-weight (HMW) glutenins in wheat) via the formation of these intermolecular crosslinks can successfully develop the texturized products with strong protein structure and extraordinary functional properties; such as enhanced dough strength and elasticity, waterholding capacity (WHC), and thermal stability (Gaspar and de Góes-Favoni, 2015).

There is a high number of review articles published in the field of TGase role in the texturization and functionality modification of food-grade proteins for food applications (Kuraishi et al., 2001; DeJong and Koppelman, 2002; Jaros et al., 2006; Lee and Chin, 2010; Kieliszek and Misiewicz, 2014; Gaspar and de Góes-Favoni, 2015; Santhi et al., 2017). Although use of this functional enzyme on the quality improvement of dairy (Jaros et al., 2006) and meat (Santhi et al., 2017) products has been comprehensively reviewed, there is no specific review in relation to the effect of TGase on the quality of wheat-based products. Moreover, to the best of our knowledge, no effort has been made so far to compile an updated and comprehensive review in the field of recent developments of noodles and pasta products texturized by TGase. Consequently, the current state-of-the-art potentials of this functional enzyme in the improving 


\section{ACCEPTED MANUSCRIPT}

physicochemical, textural, microstructural, color, sensorial and nutritional quality properties of noodles and pasta products will be displayed.

\section{Noodle and Pasta: Main Differences in Formulation and Processing}

Table 1 reveals the differences present in formulation and processing of noodle and pasta products. The unleavened doughs to prepare noodle and pasta are mainly based on common and durum wheat flours, respectively. Although flour of whole wheat and buckwheat is also used to formulate pasta products, a more diversity in flour used to prepare noodle dough (e.g., buckwheat, rice, oat, pea, mungbean, lupin, acorn, corn, etc) is observed. As pasta doughs are composed of semolina, their hardness and elasticity amounts are more than those of noodle doughs made of common wheat flours. Noodles are usually prepared in different forms of fresh, dried, deep-fried, parboiled, and steamed with a light color, while pasta products are only produced in two types of fresh and dried with an intense golden color. Overall, salt is a main ingredient in formulation of noodle, while diverse products of pasta usually are salt-free. The addition of 2-3\% salt to Asian noodles can significantly improve the noodle texture by strengthening the gluten structure to increase viscoelasticity (Hou, 2001). Egg is also considered as an essential component in processing noodles and fresh pastas. Even so, there are no egg solids in the composition of dried pastas. Also, there is no considerable variation in the received calorie quantities between noodle and pasta. Cooking process for noodles is faster than pasta products and typically served in a cold/hot seasonal broth (Table 1).

There is an obvious variance in production technology of noodles and pastas. Noodles and pastas are respectively produced by "sheeting or roll-and-cut" and "extrusion" processes (Table 


\section{ACCEPTED MANUSCRIPT}

1). Noodle products obtained by sheeting and cutting rolls are in form of thin rod, while pasta products produced during extrusion process have many forms; such as cylinders (spaghetti and macaroni), sheets (lasagna), swirls (fusilli), tubes and thin rod (Table 1).

For the preparation of instant noodles, the salt, egg, starch, flavoring agents, and other ingredients (with the exception of flour) in water are dissolved using a mixer. After adding the resulted mixture to the flour, a rest time is required to the dough maturity/development. After this step, the matured dough is kneaded to evenly distribute the imparted constituents and to wholly hydrate all the flour particles. To develop noodle strands with defined sizes, the obtained dough is then passed through rotating rollers to prepare two noodle sheets and then combined into a single sheet. The noodle sheet can similarly go through the rollers to fold again. This additional step can contribute to more develop the gluten network and the chewy texture in noodles (Hou and Kruk, 1998; Fu, 2008). A rotating slitter immediately can cut noodle strands of ideal width. The existence of some metal blocks/weights on the conveyor belt before the slitter can provide a wavy appearance for noodle strands. The noodle-strands are transferred to a steamer $\left(90-100{ }^{\circ} \mathrm{C}\right.$ for $\left.1-5 \mathrm{~min}\right)$ with the aim of the cooking, starch gelatination and fixation of noodle waves. Sometimes, the steamed noodles prior to drying step into a dipping bath are immersed in liquid seasoning. This step can be removed by adding seasonings to the noodle strands before cutting and molding into the blocks (Hou and Kruk, 1998; Gulia et al., 2014). Drying is the following stage in the noodle processing which can be implemented in two ways: (i) frying in oil (instant fried noodles) and (ii) drying with hot air (instant dried noodles). Both processes of frying $\left(140-160^{\circ} \mathrm{C}\right.$ for $\left.1-2 \mathrm{~min}\right)$ or hot-air drying $\left(\mathrm{HAD}, 70-90^{\circ} \mathrm{C}\right.$ for $\left.30-40 \mathrm{~min}\right)$ not only lead to more cook the product but also facilitate the starch gelatination and formation of an 


\section{ACCEPTED MANUSCRIPT}

extremely porous and open structure to increase the rehydration rate (Gatade and Sahoo, 2015). Under the above operating conditions, the moisture content in HAD is reduced from 30-50\% at the steaming phase to $8-12 \%$, while the fried noodles show a moisture reduction by $2-5 \%$ (Hou and Kruk, 1998; Gulia et al., 2014). Generally, the frying is a better method compared to the HAD to produce instant noodles. This fact can be attributed to the irregular hot-air distribution on the noodle surface and its subsequent undesirable effects on the texture of the final product, longer cooking time and more reduction of the flavor sensory attribute (Gulia et al., 2014). In addition, use of edible oils with low amounts of unsaturated fatty acids and also strong antioxidants can significantly extend the shelf life of fried noodles by decreasing their oxidation rate (Lim et al., 2017). The dried samples after the drying step (HAD/frying) are finally cooled to pack into a bowl or a cup containing a hot vegetable soup or seasonings. In an industrial scale, products are spontaneously excluded from the assembly line after the cooling stage if a metal material is identified or their weight is out of the pre-set range. The industrial production process of instant noodles is depicted in Fig. 1.

For the pasta production, several key processing steps including mixing, kneading/extrusion, drying, and packaging are involved. Mixing stage is performed to prepare the pasta dough mixture with a moisture content of $\sim 30 \%$ by blending pre-assessed ratios of durum wheat flour (semolina), some pseudo-cereal flours, water, egg emulsion (in some cases) and other components for 12-15 min into a mixer. However, the main function of in this phase is to uniformly distribute water among semolina particles and also to limit the formation of particle aggregates (Dalbon et al., 1996). This step can be under the vacuum in a continuous press because the air existence in dough pasta not only can provide a white, chalky appearance but also 


\section{ACCEPTED MANUSCRIPT}

can significantly alleviate the mechanical resistance of finished pasta (Icard-Verniere and Feillet, 1999). An extruder system is applied to develop pasta products by the implementing stages of kneading and shaping. The kneading stage is usually implemented under vacuum to produce resistant doughs with even distribution of gluten and moisture and without any air bubbles. Thus, this step is an important process to reach a constant textural and color property in the final product (Feillet and Dexter, 1996). Most presses have kneading perforated metal plates of at the end of the screw. Perforated metal plates mainly knead the dough into small-size streams and then mix them again on the other side of the plate to avoid inequalities of the pasta doughs. The gluten matrix after passing through these plates is much more continuous and starch granules are obviously aligned along the direction of flow (Harper and Clark, 1979). This basic operation usually is associated with heat generation. For this reason, there is a water-cooling jacket in surrounding of extrusion cylinders in order to maintain interior temperature $\left(45-50^{\circ} \mathrm{C}\right)$ of the extruder (Mariotti et al., 2011). Drying is considered as the last processing step for industrially producing pasta products with an extended shelf life This process at both relatively low $\left(60-70^{\circ} \mathrm{C}\right.$ for $10-15 \mathrm{~h})$ and high $\left(60-120^{\circ} \mathrm{C}\right.$ for $\left.2-10 \mathrm{~h}\right)$ temperatures reduces the $\mathrm{RH}$ of the unleavened pasta doughs from 32-35\% to less than 12.5\% (Cubadda et al., 2007; Piwińska et al., 2016). However, advancement of drying systems is very imperative to achieve the effective heat and mass transfer coefficients (Li et al., 2014b).

\section{New Microbial Sources of TGase}

Several new microbial sources to produce TGases with their isolation origins and enzyme activities in the diverse fermentation modes are represented in Table 2. The maximum (4.3 


\section{ACCEPTED MANUSCRIPT}

$\mathrm{U} / \mathrm{mL})$ and minimum $(0.2 \mathrm{U} / \mathrm{mL})$ enzyme activities among the investigated strains were for TGases of Streptomyces mobaraense DSM 40587 (Zhang et al., 2012a) and Streptomyces sp. polar strains (Bahrim et al., 2010), respectively. Microbial TGase (MTGase) biosynthesized by Streptomyces sp. CBMAI 837 (4.18 U/mL), S. hygroscopicus WSH 03-01 (3.2 U/mL), S. mobaraense CECT 3230 (2.95 U/mL), and Bacillus circulans BL32 (2.55 U/mL) also showed the high activities after the purification steps (Table 2). Generally, the main sources for MTGases considered strains of Bacillus, Streptomyces, Enterobacter, Providencia and Actinomycete. Although fed-batch submerged and solid state fermentations have been utilized to synthesize TGase from S. hygroscopicus WSH 03-01, MTGases extraction was mainly done in an Erlenmeyer flask system (Table 2). This fact demonstrates a special attention should be paid to design and develop fermentation systems in terms of novel bioreactors for enhancing the production yield and activity of MTGases.

\section{Structural Functions and Safety Issues of MTGase}

An acyl transfer reaction is catalyzed by TGase or glutaminyl-peptide-amine $\gamma$-glutamyl transferase (EC 2.3.2.13) between a $\gamma$-carboxyamide group in protein-bound glutamine residues (acyl donor) and an $\varepsilon$-amino group in a protein-bound lysine residue (acyl acceptor) to create covalent crosslinks of inter- or intramolecular $\varepsilon$-( $\gamma$-glutamine)-lysine isopeptidic bonds (Folk \& Finlayson, 1977). Formation of the polymerized protein matrix $\left(10^{6}-10^{7} \mathrm{~g} / \mathrm{mol}\right)$ as a result of covalent bonds supports an opportunity to stabilize pharmaceutical/food-grade gels by changing surface hydrophobicity of protein molecules (Damodaran and Agyare, 2013; Gaspar and de Góes-Favoni, 2015). It has been proved that water in case of absence of lysine residues, free 


\section{ACCEPTED MANUSCRIPT}

lysine unit and/or primary amine groups can play a key role in accepting the acyl group. The glutamine residues under this condition are hydrolytically deamidated and accordingly the acyl unit is transformed into glutamic acid. This biochemical reaction is adequate to vary the surface charge of proteins and their solubility amount (De Jong and Koppelman, 2002). A modification in solubility rate can meaningfully adjust other functionalities in terms of gelation, thickening, WHC, emulsification and foaming mechanisms (Gaspar and de Góes-Favoni, 2015).

Although there are conflicting issues in the field of MTGase safety, the FDA has approved this enzyme with No. GRN 000095 as "Generally Recognized as Safe (GRAS)" since 1998 (FDA, 2001). MTGase has also affirmed in the US, Japan and Europe as a safe component in food processing (Gerrard et al., 2000). On 24 Nov. 2007, an Interim Marketing Authorization (IMA) in Canada was published to utilize MTGase at certain levels in formulation of different pre-wrapped poultry products and solid cut meats in the presence and absence of phosphate salts. The evaluated amounts were in accordance with the standard of Good Manufacturing Practice (Health Canada, 2016).

\section{Effect of MTGs Addition on the Quality Properties}

\section{Physical Characteristics}

Changes of the physical properties (e.g., density, thickness, appearance, adhesiveness/stickiness, total organic matter (TOM), cooking loss/yield, and fat and water uptake) of noodles and pasta products as affected by the MTGase addition are indicated in Table 3. The MTGase addition led to a significant increase in dough density of fresh yellow alkaline noodle because of cross-linking enhancement within the protein network (Bellido and Hatcher, 


\section{ACCEPTED MANUSCRIPT}

2010). Although Yeoh et al. (2014) showed that canned yellow alkaline noodles based on soy protein isolate (SPI) and MTGase had the lowest thickness value, a rise in MTGase concentration from 0 to $0.6 \%$ did not significantly affect the thickness of white salted noodles made from Korean wheat cultivars (Kang et al., 2014). Li et al. (2013) pointed out that the MTGase supplementation of capsaicin-enriched layered noodles did not affect the appearance. There was no significant difference in stickiness levels between the Moringa leaves powderenriched noodles incorporated with MTGase and control samples (Limroongreungrat et al., 2011). The MTGase decreased stickiness amount of gluten-free hydroxy propyl methyl cellulose (HPMC) based pasta (Shokri et al., 2017); while the MTGase incorporation at concentration of $0.4 \%$ increased the stickiness quantity of bran supplemented spaghetti (Basman et al., 2006).

The TOM analysis demonstrated that the MTGase can significantly decrease its amount in rice and corn noodles (Yalcin and Basman, 2008a,b), and bran supplemented spaghetti (Basman et al., 2006). The robust covalent crosslinks created by MTGase can be a dependable explanation for the decrement of TOM content. This formed network matrix limits the migration of starch granules during cooking process by their covering into a firm molecular package (Yalcin and Basman, 2008a). Rosa-Sibakov et al. (2016) reported that there was no cooking loss for glutenfree pastas based on faba bean flour (FBF)-MTGase or starch-FBF-MTGase in comparison to the MTGase-free samples. Adding the MTGase remarkably attenuated cooking loss rate of dried white salted noodles (Wu and Corke, 2005), gluten-free pea flour noodles (Takács et al., 2007), wheat-based pasta products (Takács et al., 2008), rice noodles (Yalcin and Basman, 2008a), corn noodles (Yalcin and Basman, 2008b), vital wheat gluten (VWG)/egg albumin-oat flour based noodles (Wang et al., 2011), gluten-free rice noodles (Kim et al., 2014), milled lupin flour/bran 


\section{ACCEPTED MANUSCRIPT}

based-noodles (Bilgiçli and İbanoğlu 2015), and gluten-free HPMC based pasta (Shokri et al., 2017). SPI-yellow alkaline noodles supplemented with MTGase also had the lowest rate of cooking loss among all the investigated samples (Foo et al., 2011; Yeoh et al., 2014). High number of protein cross-links formed by MTGases can significantly provide a strong structural network and physical barrier to prevent the water penetration and accordingly to reduce the cooking loss rate (Kim et al., 2014). However, in the other studies, there were no substantial alterations in the cooking yield between the control samples and, spaghetti and white salted-, whole wheat-, and Moringa leaves powder-enriched-noodles formulated with MTGase (Aalami and Leelavathi, 2008; Limroongreungrat et al., 2011; Kang et al., 2014; Niu et al., 2017). In contrast, the MTGase incorporation into formulation of raw, dried and cooked noodles (Shiau and Chang, 2013), and fibre-enriched spaghettis (Sissons et al., 2010) caused a more cooking loss than the control. These results were unfavorable for the developed products because of leaching out of the starch granules and other solid constituents as a result of the structure breakdown (Kim et al., 2014). Therefore, protein cross-linking formed by MTGase possibly reduced the protein-starch interactions and led to an increase in release rate of starch and nonstarch constituents into the cooking water (Shiau and Chang, 2013).

A lengthy shelf life can be guaranteed by lessening the uptake and rancidity of fat/oil. Having quickly removed water molecules in this processing stage, a number of small holes are formed on the product surface areas and followed by oil used to be filled (Ziaiifar et al., 2008). Choy et al. (2010) found that the instant fried noodles supplemented with 1\% MTGase (23.6\%) had lower fat uptake compared to those were formulated without MTGase (29.8\%). Although the addition of MTGase to formulation of rice- and white salted-noodles did not show a notable effect on 


\section{ACCEPTED MANUSCRIPT}

their water uptake and swelling rates (Yalcin \& Basman, 2008a; Kang et al., 2014), a high water uptake rate was monitored for wheat-based pasta (Takács et al., 2008) and gluten-free pea flour noodle (Takács et al., 2007) by adding MTGase. However, Sissons et al. (2010) reported that the water uptake of fibre-enriched spaghetti can be diminished at MTGase concentrations more than $0.05 \%$.

\section{Chemical Characteristics}

Table 3 also shows the effect of MTGase addition on chemical properties (e.g., pH, freeamino acid groups, unextractable glutenin and salt-soluble protein and essential minerals) of noodles and pasta products. The formulation and treatment of noodles and pasta products mainly affect their $\mathrm{pH}$ values. An inverse relationship was observed between the $\mathrm{pH}$ amount and MTGase supplementation because of moderately acidic nature of the enzyme (Gan et al., 2009; Foo et al., 2011; Yeoh et al., 2014). Yeoh et al. (2011) represented a moderate pH for fresh SPIyellow alkaline noodle. $\mathrm{pH} 7.4$ was also determined as an optimum $\mathrm{pH}$ to attain the maximum capsaicin-retaining ability in chili powder-enriched layered noodles (Li et al. 2014b). The content of free amino acid can assess modification rate of proteins by MTGase. Wang et al. (2011) demonstrated that the oat noodle doughs formulated with VWG had the lower quantity of free-amino groups at high MTGase concentrations. This fact shows that the free amino groups of VWG have been consumed during the protein cross-linking reaction. Although the MTGase reduced the amount of salt soluble protein fractions in gluten-free pea flour noodles (Takács et al., 2007), a considerable rise in content of unextractable glutenin was observed with the MTGase incorporation into Chinese-style noodles (Bellido and Hatcher, 2011). MTGase also has 


\section{ACCEPTED MANUSCRIPT}

a potential to maintain essential minerals in noodles composed of milled lupin products (flour and bran) (Bilgiçli and İbanoğlu, 2015).

\section{Textural/Mechanical Characteristics}

Table 4 summarizes the product textural/mechanical and dough rheological properties of noodles and pastas as affected by the MTGase inclusion. In general, the use of MTGase in noodles and pasta products could considerably increase values of the textural characteristics. These critical attributes also could be improved with an increase in concentration of MTGase. The tensile or breaking strength of fresh SPI-yellow alkaline noodles ( 75-100 kPa), yellow SPInoodles ( 80-85 kPa), dried SPI-spaghetti (a little less than 230 gram-force (gf)), dried white salted noodles (9.6-14.3 gf), chili powder-enriched layered noodles ( $\sim 80 \mathrm{kPa})$, Moringa leaves powder-enriched noodles $(0.085-0.107 \mathrm{~N})$, and raw, dried and cooked noodles $(\sim 3.2-5.0 \mathrm{~N})$ improved with the MTGase (Wu and Corke, 2005; Aalami and Leelavathi, 2008; Gan et al., 2009; Limroongreungrat et al., 2011; Yeoh et al., 2011; Shiau and Chang, 2013; Li et al., 2014). The elasticity enhancement with the MTGase supplementation was also reported by Li et al. (2008) for fried instant buckwheat noodle (33-43\% increase rate), Gan et al. (2009) for yellow SPI-noodle ( 50-55 kPa), Bellido and Hatcher (2011) for Chinese-style noodle (152-184 MPa by analyzing the loss modulus), Yeoh et al. (2011) for fresh SPI-yellow alkaline noodle ( 50-65 kPa), Li et al. (2014) for chili powder-enriched layered noodle ( 30 kPa), and Niu et al. (2017)

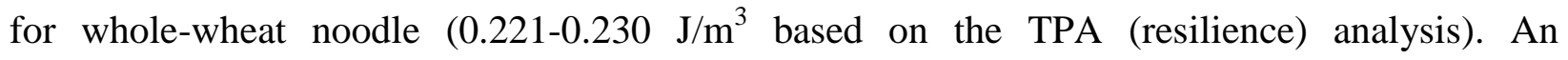
improvement in the values of hardness (Seo et al., 2003; Shin et al., 2005; Wu and Corke, 2005; Li et al., 2008; Yalcin and Basman, 2008b; Li et al., 2013; Niu et al., 2017), and firmness 


\section{ACCEPTED MANUSCRIPT}

(Basman et al., 2006; Sissons et al., 2010; Limroongreungrat et al., 2011; Kang et al., 2014), chewiness (Seo et al., 2003; Shin et al., 2005; Li et al., 2008), springiness (Yeoh et al., 2011; Niu et al., 2017), gumminess (Seo et al., 2003; Wu and Corke, 2005), adhesiveness (Li et al., 2008; Limroongreungrat et al., 2011), and cohesiveness (Li et al., 2008) for the different noodle/pasta formulations were reported by supplementing the MTGase.

The better-quality texture can be directly related to the decline of dough softening degree (Shokri et al., 2017), and improvement of dough mechanical strength (Bellido and Hatcher, 2010; Sissons et al., 2010), stability (Seo et al., 2003; Shin et al., 2005; Niu et al., 2017; Shokri et al., 2017), and development time (Kim et al., 2014; Niu et al., 2017; Shokri et al., 2017). MTGase cross-linking reactions of heterogeneous proteins can significantly reinforce the texture through the formation of strong protein networks between the starch granules (Folk and Finlayson, 1977). Some researchers analyzed the oscillatory rheological parameters (e.g., storage $\left(G^{\prime}\right)$ and loss $\left(G^{\prime \prime}\right)$ moduli) of noodle dough sheets and found that the MTGase incorporation can significantly improve their rheology (Wu \& Corke, 2005; Bellido \& Hatcher, 2010; Wang et al., 2011; Kim et al., 2014). Increasing the $G^{\prime}$ and $G^{\prime \prime}$ amounts with increasing MTGase concentration may be attributed to the more cross-linking of MTGase between the additional residues of lysine and glutamine amino acids in the protein structure (Larre et al., 2000). Bellido and Hatcher (2010) utilized low-intensity ultrasound as a suitable tool to identify the variations of dough mechanical characteristics of fresh yellow alkaline noodles. They demonstrated that the use of MTGase concentrations more than $2 \%$ in noodle formulation can be remarkably reduced and enhanced the attenuation and velocity of ultrasonic longitudinal waves, respectively. In addition, effects of cooking (Yeoh et al., 2011), and retort canning (Yeoh et al., 2014) on some 


\section{ACCEPTED MANUSCRIPT}

textural characteristics of noodles and pasta products formulated with MTGase have been recently studied. These researchers concluded that the thermal processing can cause a noticeable reduction in values of textural properties and the structural integrity of SPI-yellow alkaline noodles. Increasing the moisture diffusion in terms of penetration of water molecules during heating can lead to the physicochemical variations of proteins (the integrity reduction and surface disruption) and starch granules (fast swelling, amylose leaching and gelatinization). Having gelatinized the starch granules, they were unable to reinforce the noodles elasticity and to restitute their mechanical energy. Therefore, the interior gel structure containing swollen granules gradually got softer by increasing the process time (Hatcher et al., 2009).

\section{Microstructural Characteristics}

Many studies showed that the use of MTGase can pronouncedly improve the structural integrity and density and connectivity degree of protein matrixes through formation of the covalent cross-links of $\varepsilon$-( $\gamma$-glutamyl) lysine (Table 4$)$. Entrapment of starch granules in the strong protein network formed by MTGase can provide a potential to more keep functional ingredients incorporated into the formulations of noodle/pasta with a smoother surface (Bellido and Hatcher, 2011; Yeoh et al., 2014; Susanna and Prabhasankar, 2015; Niu et al., 2017). Wu and Corke (2005) also using a cross-sectional vision in microstructural analysis revealed a long 'channel' in the central zone of the dried white salted noodle after fracturing which was probably arisen during its dough folding. This 'channel' area could be considerably decreased by the supplementing MTGase. The MTGase inclusion into the noodle/pasta doughs can also stabilize the structural network against impacts of cooking and retort processing via enhancement of the 


\section{ACCEPTED MANUSCRIPT}

isopeptidic bonds and development of a greater amount of orientation for the protein microfibrils and starch granules (Yeoh et al., 2011; Yeoh et al., 2014). MTGase compared with glucose oxidase and endoxylanase observed the densest and most condensed gluten structure in whole wheat-noodle which could remarkably increase the dough strength and mixing stability (Niu et al., 2017).

\section{Color Characteristics}

The color attributes of noodles and pasta products were investigated in terms of $L^{*}$ (brightness/lightness), $a^{*}$ (redness), and $b^{*}$ (yellowness) values. In general, there was not a marked trend for changes of $L^{*}, a^{*}$ and $b^{*}$ color values (Table 5). The color $L^{*}$ value of fresh SPI-yellow alkaline noodle (Yeoh et al., 2011), white salted noodle (Kang et al., 2014), raw and cooked pasta (Susanna and Prabhasankar, 2015), and whole-wheat noodle (Niu et al., 2017) was increased by adding the MTGase, while a significant decrease in $L^{*}$ value was observed for yellow alkaline noodle (Foo et al., 2011), yellow SPI-noodle (Gan et al., 2009), dried white salted noodle (Wu and Corke, 2005), chili powder-enriched layered noodle (Li et al., 2014), gluten-free faba bean pasta (Rosa-Sibakov et al., 2016), and spaghetti (Aalami and Leelavathi, 2008). An enzymatic process between phenolic compounds and polyphenol oxidases under the certain reaction conditions (e.g., $\mathrm{pH}$ and ionic strength) is responsible for the product discoloration. Asenstorfer et al. (2009) reported that the addition of MTGase to the dough in different levels of $\mathrm{pH}$ and ionic strength led to a very slight change in color indexes. Therefore, the interaction of MTGase and phenolic constituents can reduce the discoloration rate by decreasing the contact level between the enzyme and substrate. The natural color (dark brown) of 


\section{ACCEPTED MANUSCRIPT}

some used flours owing to the higher amount of ash and presence of outer layers can reduce the final product brightness by facilitating enzymatic and non-enzymatic (Maillard) browning reactions during the drying step (Ramli et al., 2009; Foo et al., 2011; Rosa-Sibakov et al., 2016). Nevertheless, decreasing the $L^{*}$ value by supplementing MTGase in some noodle/pasta products can be owing to the ammonia release, its participation in the Maillard reaction and also flavones separation during the formation of covalent crosslinks between flour protein molecules (Miskelly, 1984; Wu and Corke, 2005).

There was a decrease in $a^{*}$ color level for gluten-free faba bean pasta (Rosa-Sibakov et al., 2016), and spaghetti (Aalami and Leelavathi, 2008) by the supplementing MTGase. The redness reduction may be because of the restricted levels of available lysine and thus Maillard reaction as a result of MTGase enzymatic actions (Aalami and Leelavathi, 2008). The MTGase inclusion also increased this factor in a greater number of products; such as, canned SPI-yellow alkaline noodle (Yeoh et al., 2014), rice noodle (Yalcin and Basman, 2008a), dried white salted noodle (Wu and Corke, 2005), and chili powder-enriched layered noodle (Li et al., 2014). Although an increase in level of this color parameter was found in MTGase-supplemented dried white salted noodle (Wu and Corke, 2005), spaghetti (Aalami and Leelavathi, 2008), chili powder-enriched layered noodle (Li et al., 2014), canned SPI-yellow alkaline noodle (Yeoh et al., 2014), and gluten-free faba bean pasta (Rosa-Sibakov et al., 2016) formulated with the MTGase showed a decrease in $b^{*}$ color index. Yellow color of alkaline noodles is due to the presence of high amounts of xanthophyll pigments and somewhat flavonoid components of apigenin- $C$ diglycosides in wheat flours, which naturally are colorless at acidic and neutral pHs. These compounds at alkaline pHs can be yellowish. Decrement of the color $b^{*}$ value can be, however, 


\section{ACCEPTED MANUSCRIPT}

related to the $\mathrm{pH}$ increase of the product because of leaching and the loss of alkaline salts into the water (Asenstorfer et al., 2006). Nonetheless, some other researchers found that there was no substantial difference in the color $L^{*}, a^{*}$ and $b^{*}$ values between the control and MTGasesupplemented products (Yalcin and Basman, 2008b; Choy et al., 2010; Sissons et al., 2010; Limroongreungrat et al., 2011; Bilgiçli and İbanoğlu, 2015; Shokri et al., 2017).

\section{Sensory Characteristics}

Results obtained from the sensory evaluation of noodles and pasta products indicated that the MTGase addition led to the significant improvement of sensory characteristics, so that these samples had the highest organoleptic scores in terms of appearance/surface smoothness (Takács et al., 2008; Yalcin and Basman, 2008a; Li et al., 2013), bulkiness (Basman et al., 2006), texture (hardness (Yeoh et al., 2011; Rosa-Sibakov et al., 2016), firmness (Basman et al., 2006), springiness (Yeoh et al., 2011; Li et al., 2013; Niu et al., 2017), consistency (Takács et al., 2008), and chewiness (Yalcin and Basman, 2008a; Rosa-Sibakov et al., 2016)), aroma/odor/taste (Takács et al., 2008; Li et al., 2013), and mouthfeel after chewing properties (Yalcin and Basman, 2008a,b; Niu et al., 2017). In addition, some scholars only relied to express the improved sensory quality in rice flour-based noodles at 700 ppm MTGase (Shin et al., 2005), Korean wheat flour-based noodles at 3000-7000 ppm MTGase (Seo et al., 2003), gluten-free pea flour noodles at 140 ppm MTGase (Takács et al., 2007), pseudo-cereals based pastas at $100 \mathrm{ppm}$ MTGase (Kovács, 2003), Moringa leaves powder-enriched noodles at 0.3\% MTGase (Limroongreungrat et al., 2011), and gluten-free 2\% HPMC-based pastas at 0.7\% MTGase (Shokri et al., 2017). 


\section{ACCEPTED MANUSCRIPT}

Texture and appearance are the most important sensory attributes, so that typical consumers would prefer products with desirable hardness and brightness without any discoloration (Hatcher and Anderson, 2007). The improvements on the organoleptic characteristics by MTGase were positively associated to the alterations on the dough mixing and noodle texture (hardness and elasticity) properties (Yeoh et al., 2011). The high springiness level in samples supplemented with MTGase can be due to the more adhesion of starch granules via the modification of network structure provided by protein cross-links of MTGase (Choy et al., 2010). The decrease of smoothness and/or the increase of firmness in the control sample may be attributed to the presence of more number of swollen granules with a diffused gel structure on the product surface (Ross et al., 1997; Yeoh et al., 2011). In general, an optimal level for MTGase is needed to compress a noodle/pasta between the molars because many people especially the Asian consumers prefer softer noodles or pasta products. Therefore, attendance to an ideal concentration for MTGase in noodle/pasta dough formulation is necessary to have the best sensory characteristics in a commercial scale.

\section{In vitro Starch Digestibility}

Overall, the low amount of predicted glycemic index is suitable because it shows a gentler speed of carbohydrates digestion and a lesser insulin requirement. The existence of MTGaseinduced protein cross-linking in chili powder-enriched layered noodles significantly reduced this index, so that a high retention of capsaicin in the enriched noodles was recorded due to their more resistance to digestion process ( $\mathrm{Li}$ et al., 2014). This fact can be attributed to the limited activity of enzymes and the mobility reduction of sugar substances through encapsulation of 


\section{ACCEPTED MANUSCRIPT}

starch granule cores into strong film layers (Rosa-Sibakov et al., 2016). Colonna et al. (1990) had earlier reported that proteins can successfully encapsulate starch granules to prevent the $\alpha$ amylase accessibility. A low hydrolyzing rate for in vitro starch digestion was also monitored for the yellow SPI-noodle and gluten-free faba bean pasta supplemented by MTGase (Gan et al., 2009; Rosa-Sibakov et al., 2016). This MTGase action was similar to some indigestible polymers and non-fibrous substances which were able to prevent the starch digestion under in vitro and in vivo conditions (Granfeldt et al., 1992). Moreover, it was observed that high levels of resistant starch and dietary fiber (non-starch polysaccharides) had a synergistic effect on MTGase potential to alleviate glucose absorption rate in gastrointestinal tract (Ramli et al., 2009; Li et al., 2014). Mechanisms of resistant starch and dietary fiber to decrease the starch susceptibility to be enzymatically digested are aiding the starch escape digestion and the interim barrier formation in terms of sticky gels, respectively (Eerlingen and Delcour, 1995; Chong and Aziz, 2010).

\section{Nutritional and Health Aspects}

Enrichment of noodles and pasta products with nutritive ingredients such as flour of legumes and pseudo-cereals, the bran and germ of grains, essential minerals, vitamins, antioxidant and natural pigments, flavors, antimicrobial agents and essential oils can considerably enhance the nutritional quality of these strategic products (Basman et al., 2006; Gulia et al., 2014; Elobeid et al., 2014; Li et al., 2014b; Bilgiçli and İbanoğlu, 2015; Piwińska et al., 2016; Sęczyk et al., 2016; Kazemi et al., 2017; Mridula et al., 2017; Shahsavani and Mostaghim, 2017). Fortification can be

usually carried out by direct adding the functional constituents to the used flours or liquid and powdered seasonings. Although the seasoning enrichment due to the exposure lack to 


\section{ACCEPTED MANUSCRIPT}

environmental/processing conditions (heat and moisture) and also the improved protection in packaging systems is a suitable nutritional strategy, a large problem to apply this fortification way is the unreliability of physicochemical stability of added nutrients during the storage (Gulia et al., 2014). Use of MTGase in the consumed flour gives a possibility to form a stable polymeric matrix for encapsulating many functional compounds via the generation of intricate protein bonds. For example, the spaghetti supplementation with bran can lead to difficulties in its color and cooking quality because of this fiber-rich source attenuates the gluten matrix conjunction and the dough mechanical strength (Manthey and Schorno, 2002). Basman et al. (2006) explained that the MTGase by changing the dough rheological behavior not only inhibits the protein network breakdown in the cooking operation, but also provides a healthy spaghetti with low surface stickiness by reducing the diffusion/release rate of secretions during gelatinization process of starch granules. Bilgiçli and İbanoğlu (2015) have recently reported that noodles fortified with 10-20\% lupin bran can remarkably increase the content of minerals $(\mathrm{Ca}, \mathrm{Cu}, \mathrm{Fe}$, $\mathrm{Mg}$ and $\mathrm{Zn}$ ). Therefore, the existence of MTGase-catalyzed crosslinking in the noodle dough formulation could significantly improve maintenance of these micronutrients and health benefits.

Cabrera-Chávez et al. (2008) showed that the whole/partial replacement of wheat flour with the mixture of MTGase and flour of legumes and pseudo-cereals can highly decrease the prevalence rate of celiac disease. In addition to the generation of cross-links between protein molecules, catalysis of the deamidation reaction is done by MTGase at its high concentrations, at pH 6.5 and even where there is no accessible primary amine as co-substrate (Skovbjerg et al., 2004). Since there is a unit-specific substrate (gliadin) for MTGase and tissue transglutaminase (TG2), MTGase-supplementing the foods having gliadin might thus increase immunotoxicity of 


\section{ACCEPTED MANUSCRIPT}

deamidated gliadin. Ruh et al. (2014) evaluated the immunological reactivity of gliadin-extracts obtained from control and MTGase-treated pasta doughs using the immunoblotting and ELISA techniques. No significant difference in immunoreactivity of IgA- and IgG-type antibodies present in celiac disease patients' sera was detected against gliadin extracts obtained from both pastas untreated and treated with MTGase. Similar antigenicity results were found by Takács et al. (2008) for wheat-based pasta products with a low cholesterol level.

\section{Conclusion and Future Remarks}

The present review represents a comprehensive collection of MTGase impacts on the critical quality characteristics of noodles and pasta products. This enzyme by forming heat-resistant covalent cross-links provides the suitable textural qualities for these unique products with a more breaking energy. Encapsulating the starch granules into the strong protein matrix introduced by MTGase can reinforce the dough structure, causing an inconsiderable sticky surface of final products. Increasing the cross-links number at high MTGase concentrations can significantly decrease the cooking loss rate by potentiating a physical/structural barrier against water penetration. MTGase addition to the dough formulation of noodle/pasta can clearly support a high-quality product with improved sensory and color attributes. A slow digestion rate for MTGase-supplemented products is expected because the entrapment of starch granules into closed matrix of the enzyme decelerates the movement of starch substrates and activity of hydrolyzing enzymes. Since a high capacity in consuming these healthy functional products has been recently recorded, bio-production of MTGase in large-scale industrial fermenters using superior microbial strains is of great importance. A research lack on the application of natural 


\section{ACCEPTED MANUSCRIPT}

antioxidant compounds to enrich pasta products using MTGase is also felt. It seems that the preparation of micro/nanocapsules containing nutritive ingredients using novel encapsulation techniques and their incorporation into the dough formulation can be an efficient solution to highly improve the quality of final product, and absorption/bioavailability of the target bioactive components.

\section{ACKNOWLEDGEMENTS}

The authors are very grateful to the anonymous reviewers for noteworthy suggestions and comments. Also, the authors wish to thank "World Instant Noodles Association (WINA; Shinjuku-ku, Tokyo, Japan)" for their permission to reproduce illustration present in Fig. 1.

\section{REFERENCES}

Aalami, M., and Leelavathi, K. (2008). Effect of microbial transglutaminase on spaghetti quality. Journal of Food Science, 73: 306-312.

Aidaroos, H. I., Du, G., and Chen, J. (2011). Microbial fed-batch production of transglutaminase using ammonium sulphate and calcium chloride by Streptomyces hygroscopicus. Biotechnology, Bioinformatics and Bioengineering, 1: 173-178.

Asenstorfer, R. E., Appelbee, M. J., and Mares, D. J. (2009). Physical-chemical analysis of nonpolyphenol oxidase (Non-PPO) darkening in yellow alkaline noodles. Journal of Agricultural and Food Chemistry, 57: 5556-5562. 


\section{ACCEPTED MANUSCRIPT}

Asenstorfer, R. E., Wang, Y., and Mares, D. J. (2006). Chemical structure of flavonoid compounds in wheat (Triticum aestivum L.) flour that contribute to the yellow colour of Asian alkaline noodles. Journal of Cereal Science, 43: 108-111.

Bahrim, G., Iancu, C., Buţu, N., and Negoiţă, T.G. (2010). Production of a novel microbial transglutaminase using Streptomyces sp. polar strains. Romanian Biotechnological Letters, 15: 5197-5203.

Basman, A., Koksel, H., and Atli, A. (2006). Effects of increasing levels of transglutaminase on cooking quality of bran supplemented spaghetti. European Food Research and Technology, 223: $547-551$.

Bellido, G. G., and Hatcher, D. W. (2010). Ultrasonic characterization of fresh yellow alkaline noodles. Food Research International, 43: 701-708.

Bellido, G. G., and Hatcher, D. W. (2011). Effects of a cross-linking enzyme on the protein composition, mechanical properties, and microstructure of Chinese-style noodles. Food Chemistry, 125: 813-822.

Bilgiçli, N., and İbanoğlu, Ş. (2015). Effect of milled lupin products and transglutaminase on some properties of noodle. Quality Assurance and Safety of Crops \& Foods, 7: 89-95.

Bourneow, C., Benjakul, S., and H-Kittikun, A. (2012). Hydroxamate-based colorimetric method for direct screening of transglutaminase-producing bacteria. World Journal of Microbiology and Biotechnology, 28: 2273-2277.

Cabrera-Chávez, F., Rouzaud-Sández, O., Sotelo-Cruz, N., and Calderón de la Barca, A. M. (2008). Transglutaminase treatment of wheat and maize prolamins of bread increases the 


\section{ACCEPTED MANUSCRIPT}

serum IgA reactivity of celiac disease patients. Journal of Agricultural and Food Chemistry, 56: $1387-1391$.

Chen, K., Zhang, D., Liu, S., Wang, N. S., Wang, M., Du, G., and Chen, J. (2013). Improvement of transglutaminase production by extending differentiation phase of Streptomyces hygroscopicus: mechanism and application. Applied Microbiology and Biotechnology, 97: 7711-7719.

Chong, L. C., and Aziz, N. A. A. (2010). Effects of banana flour and $\beta$-glucan on the nutritional and sensory evaluation of noodles. Food Chemistry, 119: 34-40.

Choy, A. L., Hughes, J. G., and Small, D. M. (2010). The effects of microbial transglutaminase, sodium stearoyl lactylate and water on the quality of instant fried noodles. Food Chemistry, 122: $957-964$.

Colonna, P., Barry, J. L., Cloarec, D., Bornet, F., Gouilloud, S., and Galmiche, J. P. (1990). Enzymic susceptibility of starch from pasta. Journal of Cereal Science, 11: 59-70.

Crosbie, G. B., and Ross, A. S. (2004). Asian wheat flour noodles. In: C. Wrigley (Ed.), Encyclopaedia of grain science (pp. 304-312). Oxford, UK: Elsevier Ltd.

Cubadda, R. E., Carcea, M., Marconi, E., and Trivisonno, M. C. (2007). Influence of gluten proteins and drying temperature on the cooking quality of durum wheat pasta. Cereal Chemistry, 84: 48-55.

Dalbon, G., Grivon, D., and Pagani, A. (1996). Continuous manufacturing process. In: Pasta and Noodle Technology, pp. 13-58. Kruger, J., Matsuo, R. B., and Dick, J. W. Eds., American Association Cereal Chemists, St. Paul, Minnesota. 


\section{ACCEPTED MANUSCRIPT}

Damodaran, S., and Agyare, K. K. (2013). Effect of microbial transglutaminase treatment on thermal stability and $\mathrm{pH}$-solubility of heat-shocked whey protein isolate. Food Hydrocolloids, 30: 12-18.

De Jong, G. A. H., and Koppelman, S. J. (2002). Transglutaminase catalyzed reactions: Impact on food applications. Journal of Food Science, 67: 2798-2806.

de Souza, C. F. V., Flôres, S. H., and Ayub, M. A. Z. (2006). Optimization of medium composition for the production of transglutaminase by Bacillus circulans BL32 using statistical experimental methods. Process Biochemistry, 41: 1186-1192.

de Souza, C. F. V., Venzke, J. G., Flôres, S. H., and Ayub, M. A. Z. (2011). Enzymatic properties of transglutaminase produced by a new strain of Bacillus circulans BL32 and its action over food proteins. LWT - Food Science and Technology, 44: 443-450.

Eerlingen, R. C., and Delcour, J. A. (1995). Formation, analysis, structure and properties of type III enzyme resistant starch. Journal of Cereal Science, 22: 129-138.

Elobeid, T., Berghofer, E., and Kerkadi, A. (2014). Production and determination of bioavailable iron in sorghum and white bean noodles. Current Research in Nutrition and Food Science Journal, 2: 20-25.

Eshra, D. H., El-Iraki, S. M., and Abo Bakr, T. M. (2015). Isolation and identification of Actinomycetes transglutaminase producing strains. International Journal of Current Science, 18: $76-88$.

FDA. (2001). Food and Drug Administration, Transglutaminase: GRAS notification. Washington,

D.C.,

URL 


\section{ACCEPTED MANUSCRIPT}

https://www.fda.gov/downloads/food/ingredientspackaginglabeling/gras/noticeinventory/ucm 267031.pdf [accessed on 6 June 2017].

Feillet, P., and Dexter, J. E. (1996). Quality requirements of durum wheat for semolina milling and pasta production. In: Pasta and Noodle Technology, pp. 95-131. Kruger, J., Matsuo, R. B., and Dick, J. W. Eds., American Association Cereal Chemists, St. Paul, MN.

Fink, M. L., and Folk, J. E. (1981). $\gamma$-Glutamylamine cyclotransferase. An enzyme involved in the catabolism of $\varepsilon$-( $\gamma$-glutamyl)lysine and other $\gamma$-glutamylamines. Molecular and Cellular Biochemistry, 38: 59-67.

Folk, J. E., and Finlayson, J. S. (1977). The $\varepsilon$-( $\gamma$-glutamyl) lysine cross-link and the catalytic role of transglutaminase. Advances in Protein Chemistry, 31: 1-133.

Foo, W. T., Yew, H. S., Liong, M. T., and Azhar, M. E. (2011). Influence of formulations on textural, mechanical and structural breakdown properties of cooked yellow alkaline noodles. International Food Research Journal, 18: 1295-1301.

Fu, B. X. (2008). Asian noodles: History, classification, raw materials, and processing. Food Research International, 41: 888-902.

Gan, C. Y., Ong, W. H., Wong, L. M., and Easa, A. M. (2009). Effects of ribose, microbial transglutaminase and soy protein isolate on physical properties and in-vitro starch digestibility of yellow noodles. LWT- Food Science and Technology, 42: 174-179.

Gaspar, A. L. C., and de Góes-Favoni, S. P. (2015). Action of microbial transglutaminase (MTGase) in the modification of food proteins: A review. Food Chemistry, 171: 315-322.

Gatade, A. A., and Sahoo, A. K. (2015). Effect of additives and steaming on quality of air dried noodles. Journal of Food Science and Technology, 52: 8395-8402. 


\section{ACCEPTED MANUSCRIPT}

Gerrard, J. A., Newberry, M. P., Ross, M., Wilson, A. J., Fayle, S. E., and Kavale, S. (2000). Pastry lift and croissant volume as affected by microbial transglutaminase. Journal of Food Science, 65: 312-314.

Granfeldt, Y., Björck, I., Drews, A., and Tovar, J. (1992). An in vitro procedure based on chewing to predict metabolic response to starch in cereal and legume products. European Journal of Clinical Nutrition, 46: 649-660.

Guerra-Rodríguez, E., and Vázquez M. (2014). Evaluation of a novel low-cost culture medium containing exclusively milk, potato and glycerol for microbial transglutaminase production by Streptomyces mobaraensis. Chemical Engineering Research and Design, 92: 784-791.

Gulia, N., and Khatkar, B. S. (2013). Relationship of dough thermomechanical properties with oil uptake, cooking and textural properties of instant fried noodles. Food Science and Technology International, 20: 171-182.

Gulia, N., Dhaka, V., and Khatkar, B. S. (2014). Instant noodles: Processing, quality, and nutritional aspects. Critical Reviews in Food Science and Nutrition, 54: 1386-1399.

Harper, J. M., and Clark, J. P. (1979). Food extrusion. Critical Reviews in Food Science \& Nutrition, 11: 155-215.

Hatcher, D. W., and Anderson, M. J. (2007). Influence of alkaline formulation on oriental noodles color and texture. Journal of Cereal Science, 84: 253-259.

Hatcher, D. W., Bellido, G. G., and Anderson, M. J. (2009). Flour particle size, starch damage, and alkali reagent: Impact on uniaxial stress relaxation parameters or yellow alkaline noodles. Cereal Chemistry, 86: 361-368. 


\section{ACCEPTED MANUSCRIPT}

Health Canada. (2016). Bureau of Chemical Safety, Food Directorate. Health Canada's proposal to remove "solid cut meat with or without added phosphate salts" from the list of foods that are permitted to contain transglutaminase in the list of permitted food enzymes. Notice of proposal-lists of permitted food additives. Reference number: NOP/AVP-0020.

Hou, G. (2001). Oriental noodles. Advances in Food and Nutrition Research, 43: 141-193.

Hou, G., Kruk, M., 1998. Asian noodle technology. American Institute of Baking Technical Bulletin, 20: 1-10.

H-Kittikun, A., Bourneow, C., and Benjakul, S. (2012). Hydrolysis of surimi wastewater for production of transglutaminase by Enterobacter sp. C2361 and Providencia sp. C1112. Food Chemistry, 135: 1183-1191.

Icard-Verniere, C., \& Feillet, P. (1999). Effects of mixing conditions on pasta dough development and biochemical changes. Cereal Chemistry, 76: 558-565.

Jaros, D., Partschefeld, C., Henle, T., and Rohm, H. (2006). Transglutaminase in dairy products: chemistry, physics, applications. Journal of Texture Studies, 37: 113-155.

Jin, M., Huang, J., Pei, Z., Huang, J., Gao, H., and Chang, Z. (2016). Purification and characterization of a high-salt-resistant microbial transglutaminase from Streptomyces mobaraensis. Journal of Molecular Catalysis B: Enzymatic, 133: 6-11.

Kang, C. S., Kim, K. H., Choi, I. D, Son, J. H., and Park, C. S. (2014). Effects of transglutaminase on the quality of white salted noodles made from Korean wheat cultivars. International Food Research Journal, 21: 195-202. 


\section{ACCEPTED MANUSCRIPT}

Kazemi, M., Karim, R., Mirhosseini, H., Hamid, A. A., and Tamnak, S. (2017). Processing of parboiled wheat noodles fortified with pulsed ultrasound pomegranate (Punica granatum L. var. Malas) peel extract. Food and Bioprocess Technology, 10: 379-393.

Khunthongpan, S., Bourneow, C., H-Kittikun, A., Tanasupawat, S., Benjakul, S., and Sumpavapol, P. (2013). Enterobacter siamensis sp. nov., a transglutaminase-producing bacterium isolated from seafood processing wastewater in Thailand. Journal of General and Applied Microbiology, 59: 135-140.

Kieliszek, M., and Misiewicz, A. (2014). Microbial transglutaminase and its application in the food industry. A review. Folia Microbiology, 59: 241-250.

Kim, Y., Kee, J. I., Lee, S., and Yoo, S. H. (2014). Quality improvement of rice noodle restructured with rice protein isolate and transglutaminase. Food Chemistry, 145: 409-416.

Kovács, E. T. (2003). Use of transglutaminase for developing pasta structure in pseudo-cereals systems (pp. 545-546). $3^{\text {rd }}$ International Symposium on Food Rheology and Structure. Zürich, Switzerland.

Kovács, E. T. (2009). High quality noodle products and their traditional and non-traditional processing. Journal on Processing and Energy in Agriculture, 13: 124-127.

Kuraishi, C., Yamazaki, K., and Susa, Y. (2001). Transglutaminase: its utilization in the food industry. Food Reviews International, 17: 221-246.

Larre, C., Denery-Papini, S., Popineau, Y., Deshayes, G., Desserme, C., and Lefebvre, J. (2000). Biochemical analysis and rheological properties of gluten modified by transglutaminase. Cereal Chemistry, 77: 121-127. 


\section{ACCEPTED MANUSCRIPT}

Lee, H. C., and Chin, K. B. (2010). Application of microbial transglutaminase and functional ingredients for the healthier low-fat/salt meat products: A review. Korean Journal for Food Science of Animal Resources, 30: 886-895.

Li, G., Shi, J., Yan, M., and Wang, X. (2008). Effects of transglutaminase on the quality of fried instant buckwheat noodle. Transactions of the Chinese Society of Agricultural Engineering (Transactions of the CSAE), 24: 281-287.

Li, L. Y., Easa, A. M., Liong, M. T., Tan, T. C., and Foo, W. T. (2013). The use of microbial transglutaminase and soy protein isolate to enhance retention of capsaicin in capsaicinenriched layered noodles. Food Hydrocolloids, 30: 495-503.

Li, L. Y., Tan, T. C., Liong, M. T., and Easa, A. M. (2014a). Preparation and evaluation of chili powder-enriched layered noodles. LWT - Food Science and Technology, 59: 566-571.

Li, M., Zhu, K. X., Guo, X. N., Brijs, K., and Zhou, H. M. (2014b). Natural additives in wheatbased pasta and noodle products: opportunities for enhanced nutritional and functional properties. Comprehensive Reviews in Food Science and Food Safety, 13: 347-357.

Lim, J., Jeong, S., and Lee, S. (2017). Evaluation of soybean oil-carnauba wax oleogels as an alternative to high saturated fat frying media for instant fried noodles. LWT-Food Science and Technology, 84: 788-794.

Limroongreungrat, K., Prasitkhetkit, N., and Suksomboon, A. (2011). Effect of transglutaminase on quality of noodle added with Moringa leaves powder. Agricultural Science Journal, 42: 497-500. 


\section{ACCEPTED MANUSCRIPT}

Macedo, J. A., Sette, L. D., and Sato, H. H. (2011). Purification and characterization of a new transglutaminase from Streptomyces sp. isolated in Brazilian soil. Journal of Food Biochemistry, 35: 1361-1372.

Manthey, F. A., and Schorno, A. L. (2002). Physical and cooking quality of spaghetti made from whole wheat durum. Cereal Chemistry, 79: 504-510.

Mariotti, M., Iametti, S., Cappa, C., Rasmussen, P., and Lucisano, M. (2011). Characterisation of gluten-free pasta through conventional and innovative methods: evaluation of the uncooked products. Journal of Cereal Science, 53: 319-327.

Miskelly, D. M. (1984). Flour components affecting paste and noodle colour. Journal of the Science of Food and Agriculture, 35: 463-471.

Motoki, M., and Seguro, K. (1998). Transglutaminase and its use for food processing. Trends in Food Science \& Technology, 9: 204-210.

Mridula, D., Gupta, R. K., Khaira, H., and Bhadwal, S. (2017). Groundnut meal and carrot fortified pasta: optimization of ingredients level using RSM. Proceedings of the National Academy of Sciences, India Section B: Biological Sciences, 87: 277-288.

Niu, M., Hou, G. G., Kindelspire, J., Krishnan, P., and Zhao, S. (2017). Microstructural, textural, and sensory properties of whole-wheat noodle modified by enzymes and emulsifiers. Food Chemistry, 223: 16-24.

Piwińska, M., Wyrwisz, J., Kurek, M., and Wierzbicka, A. (2016). Effect of oat $\beta$-glucan fiber powder and vacuum-drying on cooking quality and physical properties of pasta. CyTAJournal of Food, 14: 101-108. 


\section{ACCEPTED MANUSCRIPT}

Raczynski, G., Snochowski, M., and Buraczewski, S. (1975). Metabolism of $\varepsilon$-( $\gamma$-L-glutamyl)-Llysine in the rat. British Journal of Nutrition, 34: 291-296

Ramli, S., Alkarkhi, A. F. M., Yeoh, S. Y., Liong, M. T., and Easa, A. M. (2009). Effect of banana pulp and peel flour on physicochemical properties and in vitro starch digestibility of yellow alkaline noodles. International Journal of Food Sciences and Nutrition, 60: 326-340.

Rosa-Sibakov, N., Heiniö, R. L., Cassan, D., Holopainen-Mantila, U., Micard, V., Lantto, R., and Sozer, N. (2016). Effect of bioprocessing and fractionation on the structural, textural and sensory properties of gluten-free faba bean pasta. LWT- Food Science and Technology, 67: $27-36$.

Ross, A. S., Quail, K. J., and Crosbie, G. B. (1997). Physicochemical properties of Australian flours influencing the texture of yellow alkaline noodles. Cereal Chemistry, 74: 814-820.

Ruh, T., Ohsam, J., Pasternack, R., Yokoyama, K., Kumazawa, Y., and Hils, M. (2014). Microbial transglutaminase treatment in pasta-production does not affect the immunoreactivity of gliadin with celiac disease patients' sera. Journal of Agricultural and Food Chemistry, 62: 7604-7611.

Sakamoto, H., Yamazaki, K., Kaga, C., Yamamoto, Y., Ito, R., and Kurosawa, Y. (1996). Strength enhancement by addition of microbial transglutaminase during Chinese noodle processing. Nippon Shokuhin Kagaku Kogaku Kaishi, 43: 598-602.

Santhi, D., Kalaikannan, A., Malairaj, P., \& Arun Prabhu, S. (2017). Application of microbial transglutaminase in meat foods: A review. Critical Reviews in Food Science and Nutrition, 57: 2071-2076. 


\section{ACCEPTED MANUSCRIPT}

Sęczyk, Ł., Świeca, M., Gawlik-Dziki, U., Luty, M., and Czyż, J. (2016). Effect of fortification with parsley (Petroselinum crispum Mill.) leaves on the nutraceutical and nutritional quality of wheat pasta. Food Chemistry, 190: 419-428.

Seguro, K., Kumazawa, Y., Kuraishi, C., Sakamoto, H., and Motoki, M. (1996). $\varepsilon-(\gamma-$ glutamyl)lysine moiety in crosslinked casein is an available source of lysine for rats. Journal of Nutrition, 126: 2557-2562.

Seo, H., Shin, W. S., Yoon, S., and Lee, S. (2003). Effect of microbial transglutaminase on physical and textural properties of noodles made with Korean wheat flour (Geurumil). Food Science and Biotechnology, 12: 1-8.

Shahsavani, L., and Mostaghim, T. (2017). The effect of seaweed powder on physicochemical properties of yellow alkaline noodles. Journal of Food Biosciences and Technology, 7: 2734.

Shiau, S. Y., and Chang, Y. H. (2013). Instrumental textural and rheological properties of raw, dried and cooked noodle with transglutaminase. International Journal Food Properties, 16: $1429-1441$.

Shin, W. S., Seo, H. S., Woo, G. J., and Jeong, Y. S. (2005). The effect of microbial transglutaminase on textural and sensory properties of noodles mixed with rice flour. Journal of the Korean Society of Food Science and Nutrition, 34: 1434-1442.

Shokri, F., Salehifar, M., and Azizi, M. H. (2017). Effect of hydroxy propyl methyl cellulose and microbial transglutaminase enzyme on farinograph and quality characteristics of gluten-free pasta. Iranian Journal of Food Science and Technology, 13: 123-132. 


\section{ACCEPTED MANUSCRIPT}

Sissons, M. J., Aravind, N., and Fellows, C. M. (2010). Quality of fibre-enriched spaghetti containing microbial transglutaminase. Cereal Chemistry, 87: 57-64.

Skovbjerg, H., Koch, C., Anthonsen, D., and Sjöström, H. (2004). Deamidation and cross-linking of gliadin peptides by transglutaminases and the relation to celiac disease. Biochimica et Biophysica Acta, 1690: 220-230.

Susanna, S., and Prabhasankar, P. (2015). Effect of different enzymes on immunogenicity of pasta. Food and Agricultural Immunology, 26: 231-247.

Takács, K., Gelencsér, É., and Kovács, E. T. (2008). Effect of transglutaminase on the quality of wheat-based pasta products. European Food Research and Technology, 226: 603-611.

Takács, K., Nemedi, E., Marta, D., Gelencser, E., and Kovacs, E. T. (2007). Use of the enzyme transglutaminase for developing gluten free noodle products from pea flour. Journal of Acta Alimentaria, 36: 195-205.

UNAFPA. (2016). Union of Organisations of Manufacturers of Pasta Products of the EU. www.pasta-unafpa.org/ingstatistics5.htm (accessed 24.12.16.).

Wang, F., Huang, W., Kim, Y., Liu, R., and Tilley, M. (2011). Effects of transglutaminase on the rheological and noodle-making characteristics of oat dough containing vital wheat gluten or egg albumin. Journal of Cereal Science, 54: 53-59.

WINA. (2016a). World Instant Noodles http://instantnoodles.org/en/noodles/market.html (accessed 24.12.16.).

WINA. (2016b). World Instant Noodles $\quad$ Association. http://instantnoodles.org/en/noodles/process.htm (accessed 24.12.16.). 


\section{ACCEPTED MANUSCRIPT}

Wu, J., and Corke, H. (2005). Quality of dried white salted noodles affected by microbial transglutaminase. Journal of the Science of Food and Agriculture, 85: 2587-2594.

Yalcin, S., and Basman, A. (2008a). Effects of gelatinisation level, gum and transglutaminase on the quality characteristics of rice noodle. International Journal of Food Science and Technology, 43: 1637-1644.

Yalcin, S., and Basman, A. (2008b). Quality characteristics of corn noodles containing gelatinized starch, transglutaminase and gum. Journal of Food Quality, 31: 465-479.

Yamazaki, K., Naruto, Y., Tanno, H., and Soeda, T. (2004). Effects of microbial transglutaminase on texture improvement of Chinese noodles. Journal of the Japanese Society for Food Science and Technology, 51: 13-17.

Yeoh, S. Y., Alkarkhi, A. F. M., and Easa, A. M. (2014). Effect of cross-linking agents on physicochemical, textural properties and microstructure of canned soy protein isolate-yellow alkaline noodles prepared by retort processing. Journal of Food Processing and Preservation, 38: 1187-1197.

Yeoh, S. Y., Alkarkhi, A. F. M., Ramli, S., and Easa, A. M. (2011). Effect of cooking on physical and sensory properties of fresh yellow alkaline noodles prepared by partial substitution of wheat flour with soy protein isolate and treated with cross-linking agents. International Journal of Food Sciences and Nutrition, 62: 410-417.

Zhang, L., Zhang, L., Han, X., Du, M., Zhang, Y., Feng, Z., Yi, H., and Zhang, Y. (2012a). Enhancement of transglutaminase production in Streptomyces mobaraensis as achieved by treatment with excessive $\mathrm{MgCl}_{2}$. Applied Microbiology and Biotechnology, 93: 2335-2343. 


\section{ACCEPTED MANUSCRIPT}

Zhang, L., Zhang, L., Yi, H., Du, M., Ma, C., Han, X., Feng, Z., Jiao, Y., and Zhang, Y. (2012b). Enzymatic characterization of transglutaminase from Streptomyces mobaraensis DSM 40587 in high salt and effect of enzymatic cross-linking of yak milk proteins on functional properties of stirred yogurt. Journal of Dairy Science, 95: 3559-3568.

Ziaiifar, A. M., Achir, N., Courtois, F., Trezzani, I., and Trystram, G. (2008). Review of mechanisms, conditions, and factors involved in the oil uptake phenomenon during the deepfat frying process. International Journal of Food Science and Technology, 43: 1410-1423. 


\section{ACCEPTED MANUSCRIPT}

\section{Figure Caption}

Fig. 1. The production process of instant noodles. Permitted to reproduce from WINA (2016b)
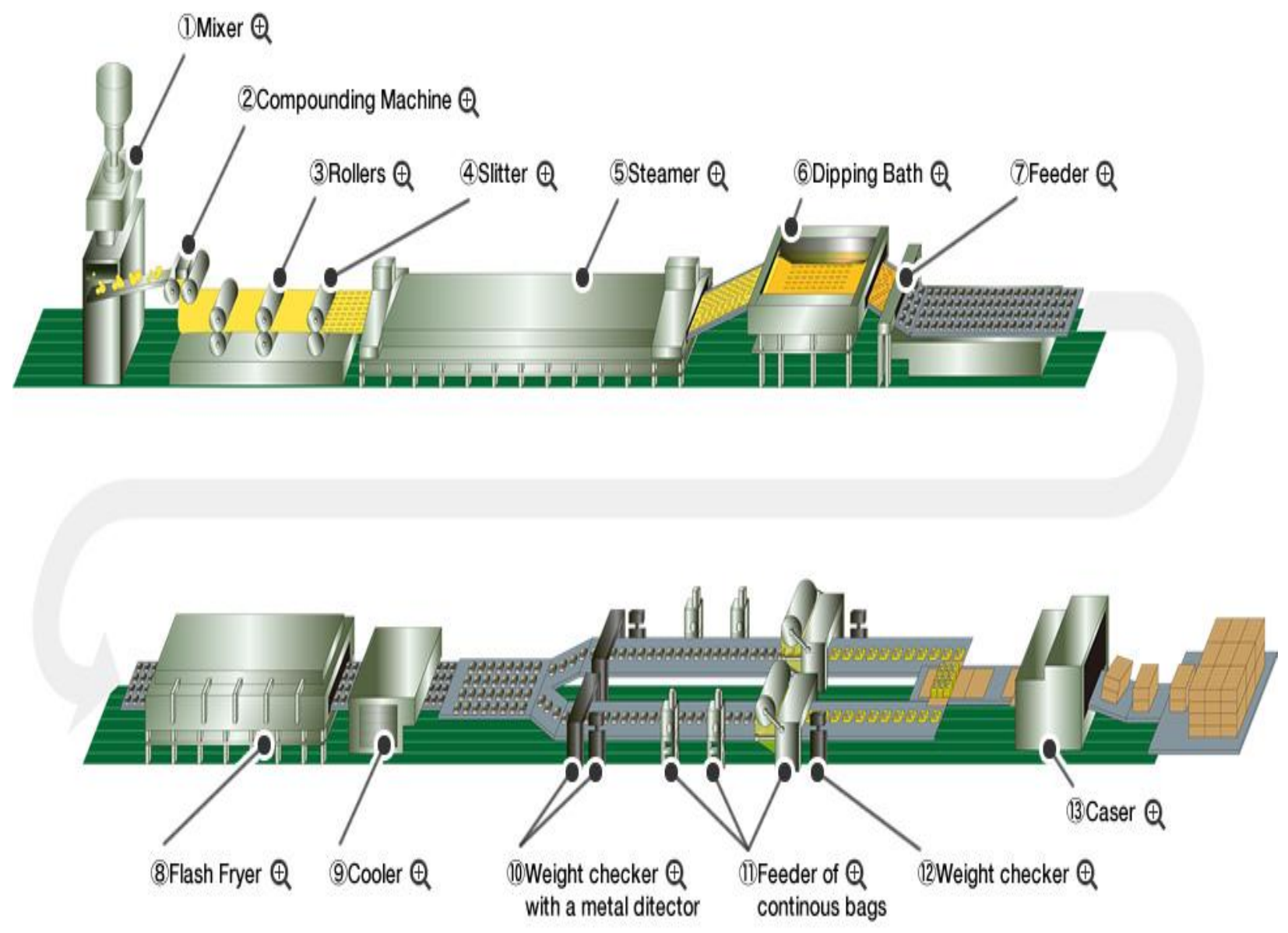


\section{ACCEPTED MANUSCRIPT}

Table 1 The main differences between noodle and pasta

\begin{tabular}{|c|c|c|}
\hline Differentiating factor & Noodle & Pasta \\
\hline Origin & Asia & Europe, Arabia \\
\hline Definition & $\begin{array}{l}\text { Prepared from unleavened dough and cooked in } \\
\text { boiling water }\end{array}$ & $\begin{array}{l}\text { Made of unleavened dough, wheat, buckwheat } \\
\text { and water }\end{array}$ \\
\hline Usual flours & $\begin{array}{l}\text { Wheat, buckwheat, rice, mungbean, lupin, acorn, } \\
\text { corn, potato, canna starch }\end{array}$ & Durum wheat, whole wheat, buckwheat \\
\hline Wheat flour type & Common & Durum (semolina) \\
\hline Salt in formulation & $(+)$ & Mostly salt-free (-) \\
\hline Egg in formulation & No less than $5.5 \%$ egg solids & Dried (-), Fresh (+) \\
\hline Texture/Structure & Softer/Smooth, silky & Harder/Strong, elastic \\
\hline Color & Lighter & More golden \\
\hline Calories & Higher; 138 (per $100 \mathrm{~g}$ ) & Lower; $\sim 131$ (per $100 \mathrm{~g})$ \\
\hline Cooking speed & Quick & Slow \\
\hline $\begin{array}{l}\text { Serving traditional } \\
\text { conditions }\end{array}$ & In a hot or cold seasonal broth & Addition of a sauce (after boiling) \\
\hline Product type for sale & Fresh, dried, deep-fried, parboiled, steamed & Fresh, dried \\
\hline Shopping cost & Cheap & Can be expensive \\
\hline Product shape & Thin rod & $\begin{array}{l}\text { Thin rod, tubes, or cylinders (spaghetti and } \\
\text { macaroni), sheets (lasagna), swirls (fusilli) }\end{array}$ \\
\hline $\begin{array}{l}\text { Manufacturing } \\
\text { technology } \\
\text { Technology simple } \\
\text { illustration }\end{array}$ & "Sheeting or roll-and-cut" process & "Extrusion" process \\
\hline Products illustration & & \\
\hline
\end{tabular}




\section{ACCEPTED MANUSCRIPT}

Table 2 Some new microbial sources producing TGase

\begin{tabular}{|c|c|c|c|c|}
\hline Microorganisms & Bacterial origin & $\begin{array}{l}\text { Cultivation } \\
\text { system }\end{array}$ & $\begin{array}{l}\text { Activity } \\
\text { (U/mL) }\end{array}$ & References \\
\hline $\begin{array}{l}\text { Bacillus circulans } \\
\text { BL32 }\end{array}$ & $\begin{array}{l}\text { Aquatic environment (Amazon basin } \\
\text { region, Brazil) }\end{array}$ & $\begin{array}{l}\text { Erlenmeyer } \\
\text { flasks }\end{array}$ & 2.55 & de Souza et al. (2011) \\
\hline $\begin{array}{l}\text { Bacillus circulans } \\
\text { BL32 }\end{array}$ & $\begin{array}{l}\text { Aquatic environment (Amazon basin } \\
\text { region, Brazil) }\end{array}$ & $\begin{array}{l}\text { Erlenmeyer } \\
\text { flasks }\end{array}$ & 0.306 & de Souza et al. (2006) \\
\hline Actinomycete strains & $\begin{array}{l}\text { Soil samples (Alexandria } \\
\text { Governorate, Egypt) }\end{array}$ & $\begin{array}{l}\text { Erlenmeyer } \\
\text { flasks }\end{array}$ & $\sim 0.04$ & Eshra et al. (2015) \\
\hline $\begin{array}{l}\text { Streptomyces sp. polar } \\
\text { strains }\end{array}$ & Antarctic soils & $\begin{array}{l}\text { Erlenmeyer } \\
\text { flasks }\end{array}$ & $0.20^{\mathrm{a}}$ & Bahrim et al. (2010) \\
\hline $\begin{array}{l}\text { Streptomyces sp. } \\
\text { CBMAI } 837\end{array}$ & Brazilian soil & $\begin{array}{l}\text { Erlenmeyer } \\
\text { flasks }\end{array}$ & $4.18^{\mathrm{b}}$ & Macedo et al. (2011) \\
\hline $\begin{array}{l}\text { S. hygroscopicus WSH } \\
\text { 03-01 }\end{array}$ & Soil samples (China) & Solid state & 1.74 & Chen et al. (2013) \\
\hline $\begin{array}{l}\text { S. hygroscopicus WSH } \\
03-01\end{array}$ & Soil samples (China) & Fed-batch & 3.2 & Aidaroos et al. (2011) \\
\hline S. mobaraensis TX & Soil samples (China) & $\begin{array}{l}\text { Erlenmeyer } \\
\text { flasks }\end{array}$ & $39.2^{\mathrm{b}}$ & Jin et al. (2016) \\
\hline $\begin{array}{l}\text { S. mobaraensis DSM } \\
40587\end{array}$ & - & $\begin{array}{l}\text { Erlenmeyer } \\
\text { flasks }\end{array}$ & 4.3 & Zhang et al. (2012a) \\
\hline $\begin{array}{l}\text { S. mobaraensis DSM } \\
40587\end{array}$ & - & $\begin{array}{l}\text { Erlenmeyer } \\
\text { flasks }\end{array}$ & $17.2^{\mathrm{b}}$ & Zhang et al. (2012b) \\
\hline $\begin{array}{l}\text { S. mobaraense DSM } \\
40847\end{array}$ & $\begin{array}{l}\text { Floating-floc/wastewater (Tuna } \\
\text { canning factory, Thailand) }\end{array}$ & $\begin{array}{l}\text { Erlenmeyer } \\
\text { flasks }\end{array}$ & $0.32-0.63$ & Bourneow et al. (2012) \\
\hline $\begin{array}{l}\text { S. mobaraense CECT } \\
3230\end{array}$ & - & $\begin{array}{l}\text { Erlenmeyer } \\
\text { flasks }\end{array}$ & 2.95 & $\begin{array}{l}\text { Guerra-Rodríguez \& } \\
\text { Vázquez (2014) }\end{array}$ \\
\hline $\begin{array}{l}\text { Enterobacter sp. } \\
\text { C2361 }\end{array}$ & $\begin{array}{l}\text { Wastewater of surimi industry } \\
\text { (Songkhla, Thailand) }\end{array}$ & $\begin{array}{l}\text { Erlenmeyer } \\
\text { flasks }\end{array}$ & 1.18 & H-Kittikun et al. (2012) \\
\hline E. siamensis sp. nov. & $\begin{array}{l}\text { Seafood processing wastewater } \\
\text { (Songkhla, Thailand) }\end{array}$ & - & - & $\begin{array}{l}\text { Khunthongpan et al. } \\
\text { (2013) }\end{array}$ \\
\hline Providencia sp. C1112 & $\begin{array}{l}\text { Wastewater of surimi industry } \\
\text { (Songkhla, Thailand) }\end{array}$ & $\begin{array}{l}\text { Erlenmeyer } \\
\text { flasks }\end{array}$ & 1.78 & H-Kittikun et al. (2012) \\
\hline
\end{tabular}

${ }^{\mathrm{a}}$ Reported for the best strain coded as MIUG 13P

${ }^{\mathrm{b}}$ Reported as specific activity (U/mg) 
Table 3 Effect of MTGase on the physicochemical attributes of different noodle and pasta types

\begin{tabular}{|c|c|c|c|}
\hline $\begin{array}{l}\text { Noodles and } \\
\text { pasta products }\end{array}$ & Special mention of evaluated physical properties & $\begin{array}{l}\text { Special mention of evaluated chemical } \\
\text { properties }\end{array}$ & References \\
\hline $\begin{array}{l}\text { Fresh yellow } \\
\text { alkaline noodle }\end{array}$ & $\begin{array}{l}\text { A denser matrix for noodle dough was obtained } \\
\text { with MTGase. }\end{array}$ & $\mathrm{NR}^{\mathrm{a}}$ & $\begin{array}{l}\text { Bellido \& } \\
\text { Hatcher } \\
(2010)\end{array}$ \\
\hline $\begin{array}{l}\text { Fresh SPI- } \\
\text { yellow alkaline } \\
\text { noodle }\end{array}$ & $\begin{array}{l}\text { A notable improvement in physical properties of } \\
\text { cooked noodles formulated with MTGase was } \\
\text { monitored. }\end{array}$ & $\begin{array}{l}\text { The } \mathrm{pH} \text { value for MTGase-noodles } \\
\text { was moderate. }\end{array}$ & $\begin{array}{l}\text { Yeoh et al. } \\
(2011)\end{array}$ \\
\hline $\begin{array}{l}\text { Canned SPI- } \\
\text { yellow alkaline } \\
\text { noodle }\end{array}$ & $\begin{array}{l}\text { SPI-MTGase had the lowest retort cooking loss } \\
\text { and thickness. }\end{array}$ & $\begin{array}{l}\mathrm{pH} \text { of thermally treated noodles was } \\
\text { less than that of untreated-ones. } \mathrm{pH} \\
\text { amounts of all samples declined by } \\
\text { retort processing. }\end{array}$ & $\begin{array}{l}\text { Yeoh et al. } \\
(2014)\end{array}$ \\
\hline $\begin{array}{l}\text { SPI-Yellow } \\
\text { alkaline noodle }\end{array}$ & $\begin{array}{l}\text { The lowest cooking yield was for SPI-MTGase } \\
\text { noodle. }\end{array}$ & $\begin{array}{l}\text { A notable decrease in } \mathrm{pH} \text { was found } \\
\text { with the addition of MTGase. }\end{array}$ & $\begin{array}{l}\text { Foo et al. } \\
\text { (2011) }\end{array}$ \\
\hline $\begin{array}{l}\text { Yellow SPI- } \\
\text { noodle }\end{array}$ & NR & $\begin{array}{l}\text { A drop from the original } \mathrm{pH} \text { was } \\
\text { found by adding MTGase to SPI-based } \\
\text { noodle formulation. }\end{array}$ & $\begin{array}{l}\text { Gan et al. } \\
(2009)\end{array}$ \\
\hline $\begin{array}{l}\text { Instant fried } \\
\text { noodle }\end{array}$ & $\begin{array}{l}\text { The fat uptake of noodle formulated with } 1.0 \% \\
\text { MTGase was lower than that of the control } \\
\text { sample. }\end{array}$ & $\begin{array}{l}\text { The extractability of proteins } \\
\text { decreased by increasing alkali level up } \\
\text { to } 1.0 \% \text {. }\end{array}$ & $\begin{array}{l}\text { Choy et al. } \\
(2010)\end{array}$ \\
\hline $\begin{array}{l}\text { Fried instant } \\
\text { buckwheat } \\
\text { noodle }\end{array}$ & $\begin{array}{l}\text { MTGase decreased time of steaming and } \\
\text { rehydration and the oil concentration in } \\
\text { formulations. }\end{array}$ & NR & $\begin{array}{l}\text { Li et al. } \\
(2008)\end{array}$ \\
\hline Rice noodle & $\begin{array}{l}\text { The cooking loss }(\sim 55 \%) \text { and water turbidity } \\
(\sim 67 \%) \text { decreased after treating noodles with } \\
\text { MTGase and rice protein isolate. }\end{array}$ & NR & $\begin{array}{l}\text { Kim et al. } \\
(2014)\end{array}$ \\
\hline Rice noodle & $\begin{array}{l}\text { MTGase had not a significant effect on the } \\
\text { cooking loss, water absorption and swelling rates. } \\
\text { Cooking loss of the MTGase-incorporated } \\
\text { samples was significantly less than those of the } \\
\text { control. The total organic matter significantly } \\
\text { decreased with the MTGase addition. }\end{array}$ & NR & $\begin{array}{l}\text { Yalcin \& } \\
\text { Basman } \\
(2008 \mathrm{a})\end{array}$ \\
\hline $\begin{array}{l}\text { Oat flour-based } \\
\text { noodle }\end{array}$ & $\begin{array}{l}1.0 \% \text { MTGase addition to noodles containing } \\
\text { gluten or egg albumin decreased the cooking loss } \\
\text { rate. }\end{array}$ & $\begin{array}{l}\text { The free amino groups number } \\
\text { changed based on the interaction of } \\
\text { protein cross-linking of MTGase. }\end{array}$ & $\begin{array}{l}\text { Wang et al. } \\
(2011)\end{array}$ \\
\hline Corn noodle & $\begin{array}{l}\text { Use of MTGase provided a final product with } \\
\text { smooth surface along with a reduction in cooking } \\
\text { loss and total organic matter amounts. }\end{array}$ & NR & $\begin{array}{l}\text { Yalcin \& } \\
\text { Basman } \\
(2008 b)\end{array}$ \\
\hline $\begin{array}{l}\text { White salted } \\
\text { noodle }\end{array}$ & $\begin{array}{l}\text { An increase in MTGase level did not change } \\
\text { water absorption and thickness amounts of the } \\
\text { noodle dough sheet and also cooking loss rate. }\end{array}$ & NR & $\begin{array}{l}\text { Kang et al. } \\
(2014)\end{array}$ \\
\hline $\begin{array}{l}\text { Dried white } \\
\text { salted noodle }\end{array}$ & $\begin{array}{l}\text { A significant decrease in cooking yield was } \\
\text { obtained by adding MTGase. }\end{array}$ & NR & $\begin{array}{l}\text { Wu \& Corke } \\
(2005)\end{array}$ \\
\hline $\begin{array}{l}\text { Whole-wheat } \\
\text { noodle }\end{array}$ & $\begin{array}{l}\text { There was no significant difference for cooking } \\
\text { yield between samples formulated with MTGase } \\
\text { and control. }\end{array}$ & NR & $\begin{array}{l}\text { Niu et al. } \\
(2017)\end{array}$ \\
\hline $\begin{array}{l}\text { Chinese-style } \\
\text { noodle }\end{array}$ & $\begin{array}{l}\text { MTGase addition led to a substantial } \\
\text { improvement in physical properties via the } \\
\text { formation of } \varepsilon-(\gamma \text {-glutamyl) lysine. }\end{array}$ & $\mathrm{NR}^{\mathrm{a}}$ & $\begin{array}{l}\text { Sakamoto et } \\
\text { al. (1996) }\end{array}$ \\
\hline
\end{tabular}




\section{Table 3 continued}

\begin{tabular}{llll}
\hline $\begin{array}{l}\text { Noodles and pasta } \\
\text { products }\end{array}$ & $\begin{array}{l}\text { Special mention of evaluated } \\
\text { physical properties }\end{array}$ & $\begin{array}{l}\text { Special mention of evaluated chemical } \\
\text { properties }\end{array}$ & References \\
\hline $\begin{array}{l}\text { Chinese-style } \\
\text { noodle }\end{array}$ & $\begin{array}{l}\text { MTGase addition led to a substantial } \\
\text { improvement in physical properties } \\
\text { via the formation of } \varepsilon \text { - }(\gamma \text {-glutamyl) } \\
\text { lysine. }\end{array}$ & $\mathrm{NR}^{\mathrm{a}}$ & $\begin{array}{l}\text { Sakamoto et al. } \\
(1996)\end{array}$ \\
$\begin{array}{l}\text { Chinese-style } \\
\text { noodle }\end{array}$ & NR & $\begin{array}{l}\text { A significant increase in unextractable } \\
\text { glutenin content by supplementing MTGase }\end{array}$ & $\begin{array}{l}\text { Bellido \& Hatcher } \\
(2011)\end{array}$ \\
$\begin{array}{l}\text { Milled lupin } \\
\text { flour/bran based- } \\
\text { noodle }\end{array}$ & $\begin{array}{l}\text { MTGase application decreased } \\
\text { cooking loss levels }\end{array}$ & $\begin{array}{l}\text { Essential mineral levels were improved by } \\
\text { increasing ratio of lupin flour }(10-30 \%) \text { and } \\
\text { bran }(10-20 \%) \text { in the presence of MTGase. }\end{array}$ & (2015)
\end{tabular}

Gluten-free pea

flour noodle

A high rate in water uptake and a low cooking loss were found by supplementing MTGase.

Capsaicinenriched layered noodle

Chili powderenriched layered noodle

Moringa leaves powder-enriched noodle

Noodle (raw, dried and cooked)

Wheat-based pasta

Pseudo-cereals based pasta

Gluten-free faba bean pasta

Gluten-free HPMC based pasta
MTGase-incoroprated noodles compared with the control had a more slippery on the surface.

Appearance of the control and MTGase-supplemented noodles was similar. NR

There were no significant differences in cooking loss and adhesiveness amounts by the adding MTGase.

A lower cooking loss $(4.98 \%)$ for control noodle was determined compared with that of noodles containing MTGase (5.84-6.12\%).

Moisture content of cooked noodle formulated with MTGase (0.5-1.5\%) was significantly lower than that of the control.

MTGase-incorporated pastas compared to the untreated ones had good cooking quality with high water uptake and low cooking loss.

The use of MTGase $(50-200 \mathrm{mg} / \mathrm{kg}$ ) led to products with excellent cooking quality.

No cooking loss for faba-MTGase or starch-faba-MTGase samples compared to the pastas without MTGase is found.

MTGase addition avoided the swollen of starch granules.

MTGase decreased cooking loss and stickiness of pasta. MTGase had no significant effect on the moisture (10-20\%) in the presence of MTGase.

A significant decrease in the water content and salt-soluble protein fractions and a change in molecular weight distributions were found by adding $50-200 \mathrm{mg} / \mathrm{kg}$ MTGase.

The capsaicin release rate in simulated gastrointestinal conditions decreased by increasing MTGase concentration.

Wheat flour-SPI based noodles containing MTGase had the highest retentive capacity of capsaicin at $\mathrm{pH}$ 7.4. The capsaicinretaining ability at $\mathrm{pH} 1.2$ was similar for all noodles.

NR

NR

Takács et al. (2007)

Li et al. (2013)

Li et al. (2014)

Quantities of protein fractions of water/salt, the alcohol- and the alkali-soluble were decreased by increasing $10-200 \mathrm{mg} / \mathrm{kg}$.

MTGase notably decreased the quantities of low-molecular weight fractions and soluble protein ones.

In fermented faba pasta, MTGase possibly could not form covalent crosslinks between protein chains.

\section{(2016)}

Limroongreungrat et al. (2011)

Shiau \& Chang (2013)

Takács et al. (2008)

Kovács (2003)

Rosa-Sibakov et al.

NR

Shokri et al. (2017) 


\section{ACCEPTED MANUSCRIPT}

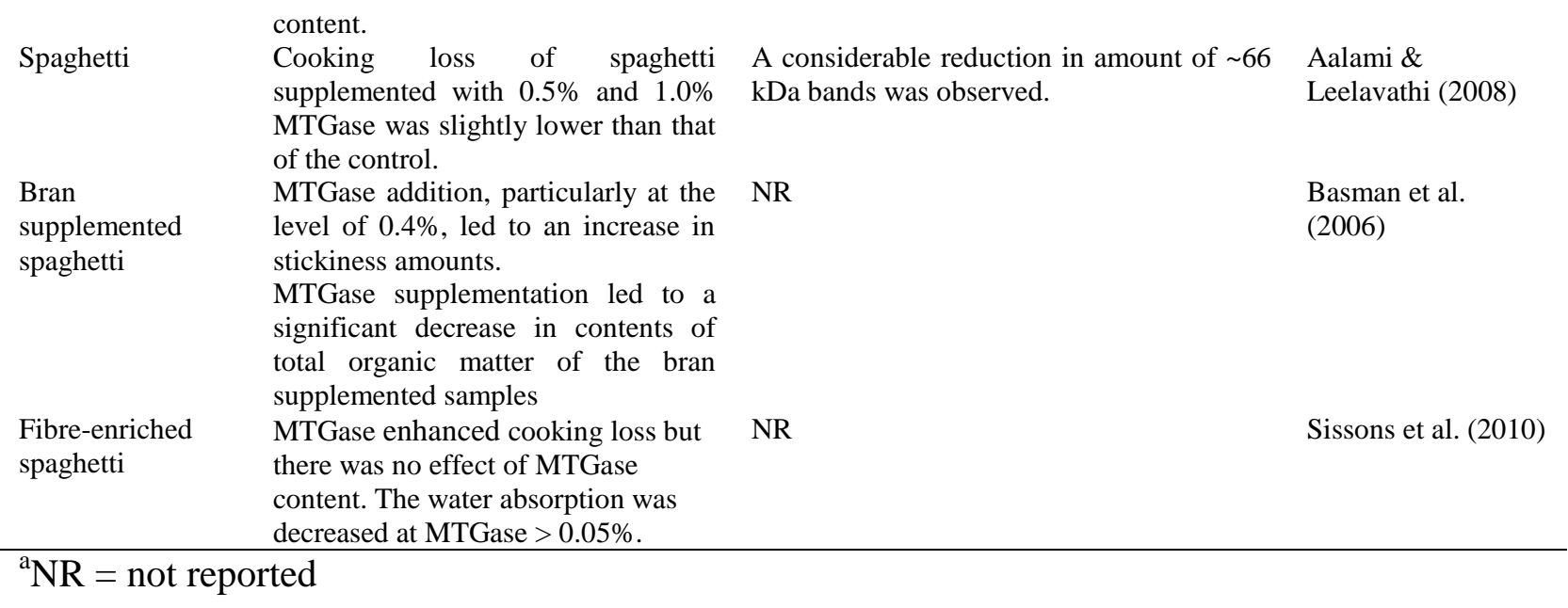


Table 4 Effect of MTGase on the textural and structural characteristics of different noodle and

\author{
pasta types
}

\begin{tabular}{|c|c|c|c|}
\hline $\begin{array}{l}\text { Noodles and } \\
\text { pasta products }\end{array}$ & $\begin{array}{l}\text { Special mention of assessed } \\
\text { textural/rheological properties }\end{array}$ & $\begin{array}{l}\text { Special mention of assessed } \\
\text { microstructural properties }\end{array}$ & References \\
\hline $\begin{array}{l}\text { Fresh yellow } \\
\text { alkaline noodle }\end{array}$ & $\begin{array}{l}\text { The mechanical strength of noodle dough was } \\
\text { increased according to the changes of } \\
\text { longitudinal mechanical moduli. }\end{array}$ & $\mathrm{NR}^{\mathrm{a}}$ & $\begin{array}{l}\text { Bellido \& } \\
\text { Hatcher } \\
(2010)\end{array}$ \\
\hline $\begin{array}{l}\text { Fresh SPI- } \\
\text { yellow alkaline } \\
\text { noodle }\end{array}$ & $\begin{array}{l}\text { A maximum value for tensile strength and } \\
\text { elasticity was recorded for the MTGase- } \\
\text { supplemented noodles. }\end{array}$ & $\begin{array}{l}\text { MTGase modified the crystallinity or } \\
\text { molecular structure of the formed matrix. }\end{array}$ & $\begin{array}{l}\text { Yeoh et al. } \\
(2011)\end{array}$ \\
\hline $\begin{array}{l}\text { Canned SPI- } \\
\text { yellow alkaline } \\
\text { noodle }\end{array}$ & $\begin{array}{l}\text { Retort processing led to a reduction in values } \\
\text { of textural parameters } \\
\text { The highest values of textural parameters was } \\
\text { for the SPI-MTGase }\end{array}$ & $\begin{array}{l}\text { Retort processing and storage reduced } \\
\text { structural complexity in SPI-MTGase and } \\
\text { SPI-ribose-MTGase }\end{array}$ & $\begin{array}{l}\text { Yeoh et al. } \\
(2014)\end{array}$ \\
\hline $\begin{array}{l}\text { SPI-Yellow } \\
\text { alkaline noodle }\end{array}$ & $\begin{array}{l}\text { SPI-MTGase noodle had the highest values of } \\
\text { textural and mechanical characteristics }\end{array}$ & $\begin{array}{l}\text { The slowest breakdown rate with a } \\
\text { highly-dense structure was for } \\
\text { SPI/MTGase noodle because of the extra } \\
\text { protein crosslinking. }\end{array}$ & $\begin{array}{l}\text { Foo et al. } \\
(2011)\end{array}$ \\
\hline $\begin{array}{l}\text { Yellow SPI- } \\
\text { noodle }\end{array}$ & $\begin{array}{l}\text { MTGase significantly increased tensile } \\
\text { strength and elasticity. }\end{array}$ & $\mathrm{NR}$ & $\begin{array}{l}\text { Gan et al. } \\
(2009)\end{array}$ \\
\hline $\begin{array}{l}\text { Instant fried } \\
\text { noodle }\end{array}$ & $\begin{array}{l}\text { MTGase improved the textural characteristics } \\
\text { of sample prepared with the low-protein flour. }\end{array}$ & $\begin{array}{l}\text { The structural expansion within the } \\
\text { noodle matrix was increased }\end{array}$ & $\begin{array}{l}\text { Choy et al. } \\
(2010)\end{array}$ \\
\hline $\begin{array}{l}\text { Fried instant } \\
\text { buckwheat } \\
\text { noodle }\end{array}$ & $\begin{array}{l}\text { MTGase improved the elasticity, } \\
\text { adhesiveness, hardness, cohesiveness, } \\
\text { chewiness and fracture force. }\end{array}$ & NR & $\begin{array}{l}\text { Li et al. } \\
(2008)\end{array}$ \\
\hline Rice noodle & $\begin{array}{l}\text { MTGase enhanced the development time and } \\
\text { maximum and peak torques of noodle dough. }\end{array}$ & $\begin{array}{l}\text { A smooth surface was arisen in cracked } \\
\text { noodle by the MTGase addition. } \\
\text { Rice noodle restructured with rice protein } \\
\text { isolate and MTGase showed a smoother } \\
\text { surface. }\end{array}$ & $\begin{array}{l}\text { Kim et al. } \\
(2014)\end{array}$ \\
\hline Rice noodle & $\begin{array}{l}\text { The maximum force was not affected by } \\
\text { MTGase incorporation followed by a resting } \\
\text { time }(1-2 \mathrm{~h}) \text { before drying }\end{array}$ & NR & $\begin{array}{l}\text { Yalcin \& } \\
\text { Basman } \\
(2008 a)\end{array}$ \\
\hline $\begin{array}{l}\text { Rice flour-based } \\
\text { noodle }\end{array}$ & $\begin{array}{l}\text { MTGase addition ( } 3000-7000 \mathrm{ppm}) \text { to the } \\
\text { dough increased its stability. } \\
\text { The chewiness and hardness values of noodles } \\
\text { formulated with } 30 \% \text { rice flour were notably } \\
\text { improved by adding } 7000 \mathrm{ppm} \text { MTGase. }\end{array}$ & $\begin{array}{l}\text { The MTGase addition strengthened the } \\
\text { noodle structure via covalent crosslinks } \\
\text { between protein molecules }\end{array}$ & $\begin{array}{l}\text { Shin et al. } \\
(2005)\end{array}$ \\
\hline Corn noodle & $\begin{array}{l}\text { MTGase addition after a } 1-2 \mathrm{~h} \text { resting period } \\
\text { before drying significantly improved values of } \\
\text { maximum force. }\end{array}$ & $\begin{array}{l}\text { Reinforcement the structural integrity was } \\
\text { found using MTGase-catalyzed } \\
\text { crosslinking. }\end{array}$ & $\begin{array}{l}\text { Yalcin \& } \\
\text { Basman } \\
(2008 b)\end{array}$ \\
\hline $\begin{array}{l}\text { White salted } \\
\text { noodle }\end{array}$ & $\begin{array}{l}\text { A larger elasticity and a firmer texture for } \\
\text { noodles supplemented with } 0.4 \% \text { MTGase in } \\
\text { comparison with the control were found. }\end{array}$ & NR & $\begin{array}{l}\text { Kang et al. } \\
(2014)\end{array}$ \\
\hline $\begin{array}{l}\text { Dried white } \\
\text { salted noodle }\end{array}$ & $\begin{array}{l}1.0 \mathrm{~g} / \mathrm{kg} \text { MTGase addition can increase the } \\
\text { storage modulus and loss modulus of fresh } \\
\text { dough sheets. } \\
\text { Hardness, tensile force and gumminess of the } \\
\text { dried samples were usually increased by } \\
\text { adding MTGase. }\end{array}$ & $\begin{array}{l}\text { Forming the cross-links of } \varepsilon \text {-( } \gamma \text {-glutamyl }) \\
\text { lysine by MTGase improved the network } \\
\text { microstructure. }\end{array}$ & $\begin{array}{l}\text { Wu \& Corke } \\
(2005)\end{array}$ \\
\hline $\begin{array}{l}\text { Whole-wheat } \\
\text { noodle }\end{array}$ & $\begin{array}{l}\text { MTGase improved the development time and } \\
\text { stability of whole-wheat dough of produced } \\
\text { noodles. } \\
\text { MTGase enhanced the hardness, springiness }\end{array}$ & $\begin{array}{l}\text { MTGase increased the connectivity of } \\
\text { gluten network and highly covered starch } \\
\text { granules in the structure of developed } \\
\text { noodles. }\end{array}$ & $\begin{array}{l}\text { Niu et al. } \\
(2017)\end{array}$ \\
\hline
\end{tabular}




\section{ACCEPTED MANUSCRIPT}

and resilience or elasticity levels of cooked

noodles.

$\begin{array}{llll}\text { Korean wheat } & \text { The dough stability and noodle textural } & \text { Structural complexity and strong network } & \text { Seo et al. } \\ \text { flour-based } & \text { characters (gumminess, hardness, chewiness) } & \text { formation was highly improved. } & (2003)\end{array}$

noodle were improved by the addition of MTGase.

${ }^{\mathrm{a}} \mathrm{NR}=$ not reported

\section{Table 4 continued}

\begin{tabular}{|c|c|c|c|}
\hline $\begin{array}{l}\text { Noodles and pasta } \\
\text { products }\end{array}$ & $\begin{array}{l}\text { Special mention of assessed textural } \\
\text { properties }\end{array}$ & $\begin{array}{l}\text { Special mention of assessed } \\
\text { microstructural properties }\end{array}$ & References \\
\hline Chinese-style noodle & $\begin{array}{l}\text { Breaking strength of pickled and } \\
\text { retorted noodles increased by } \\
\text { increasing MTGase level. } \\
\text { The boiled noodles containing } \\
\text { MTGase had a more breaking strength } \\
\text { of than the control. }\end{array}$ & $\begin{array}{l}\text { The MTGase treatment reinforced } \\
\text { protein network in the noodle structure. }\end{array}$ & $\begin{array}{l}\text { Sakamoto et al. } \\
\text { (1996) }\end{array}$ \\
\hline Chinese-style noodle & $\begin{array}{l}\text { The simultaneous adding of MTGase } \\
\text { and protein degradation products } \\
\text { compared to MTGase alone led to a } \\
\text { more improvement in the mechanical } \\
\text { properties. } \\
\text { The boiled noodles containing } \\
\text { MTGase after storing in a refrigerator } \\
\text { significantly kept their } \\
\text { mechanical/textural properties with } \\
\text { time. }\end{array}$ & $\mathrm{NR}^{\mathrm{a}}$ & $\begin{array}{l}\text { Yamazaki et al. } \\
(2004)\end{array}$ \\
\hline Chinese-style noodle & $\begin{array}{l}\text { The mechanical behaviour showed a } \\
\text { more elasticity and a meaningfully less } \\
\text { viscous by incorporating MTGase. }\end{array}$ & $\begin{array}{l}\text { MTGase reinforcing effect } \\
\text { (connectivity degree of the protein } \\
\text { network) improved the protein layer } \\
\text { thickness enveloping the starch } \\
\text { granules. }\end{array}$ & $\begin{array}{l}\text { Bellido \& Hatcher } \\
\text { (2011) }\end{array}$ \\
\hline $\begin{array}{l}\text { Gluten-free pea flour } \\
\text { noodle }\end{array}$ & NR & $\begin{array}{l}\text { The MTGase could integrate fractions } \\
\text { with low molecular weight (MW) into } \\
\text { the developed protein structure forming } \\
\text { new non-salt soluble high MW protein } \\
\text { subunits. }\end{array}$ & $\begin{array}{l}\text { Takács et al. } \\
(2007)\end{array}$ \\
\hline $\begin{array}{l}\text { Capsaicin-enriched } \\
\text { layered noodle }\end{array}$ & $\begin{array}{l}1.5 \% \text { MTG supplemented noodles } \\
\text { were the hardest and needed to a } \\
\text { maximum force to chew. } \\
\text { The hardness increased by enhancing } \\
\text { MTGase content from } 0.5 \text { to } 1.5 \% \text {. }\end{array}$ & $\begin{array}{l}\text { MTGase-supplemented noodles } \\
\text { exhibited a denser structure than the } \\
\text { control. } \\
\text { A high denseness with a low void } \\
\text { structure was observed at increased } \\
\text { concentrations of MTGase. }\end{array}$ & Li et al. (2013) \\
\hline $\begin{array}{l}\text { Chili powder-enriched } \\
\text { layered noodle }\end{array}$ & $\begin{array}{l}\text { MTGase-supplemented noodles based } \\
\text { on wheat flour-SPI had the maximum } \\
\text { tensile strength and elasticity. }\end{array}$ & $\begin{array}{l}\text { A substantial increase in covalent } \\
\text { cross-linking between protein matrices } \\
\text { with the presence of MTGase led to a } \\
\text { structural integration and a slow } \\
\text { diffusion rate for capsaicin. }\end{array}$ & Li et al. (2014) \\
\hline $\begin{array}{l}\text { Moringa leaves } \\
\text { powder-enriched } \\
\text { noodle }\end{array}$ & $\begin{array}{l}\text { A significant increase in firmness and } \\
\text { tensile strength values of cooked } \\
\text { samples was found by increasing } \\
\text { MTGase from } 0 \text { to } 0.3 \% \text {. } \\
\text { Use of high content of MTG }(0.5- \\
0.9 \%) \text { led to a decrease in textural }\end{array}$ & $\begin{array}{l}\text { An improvement in network } \\
\text { microstructure was obtained by adding } \\
\text { MTGase to the formulation. }\end{array}$ & $\begin{array}{l}\text { Limroongreungrat } \\
\text { et al. (2011) }\end{array}$ \\
\hline
\end{tabular}




\section{ACCEPTED MANUSCRIPT}

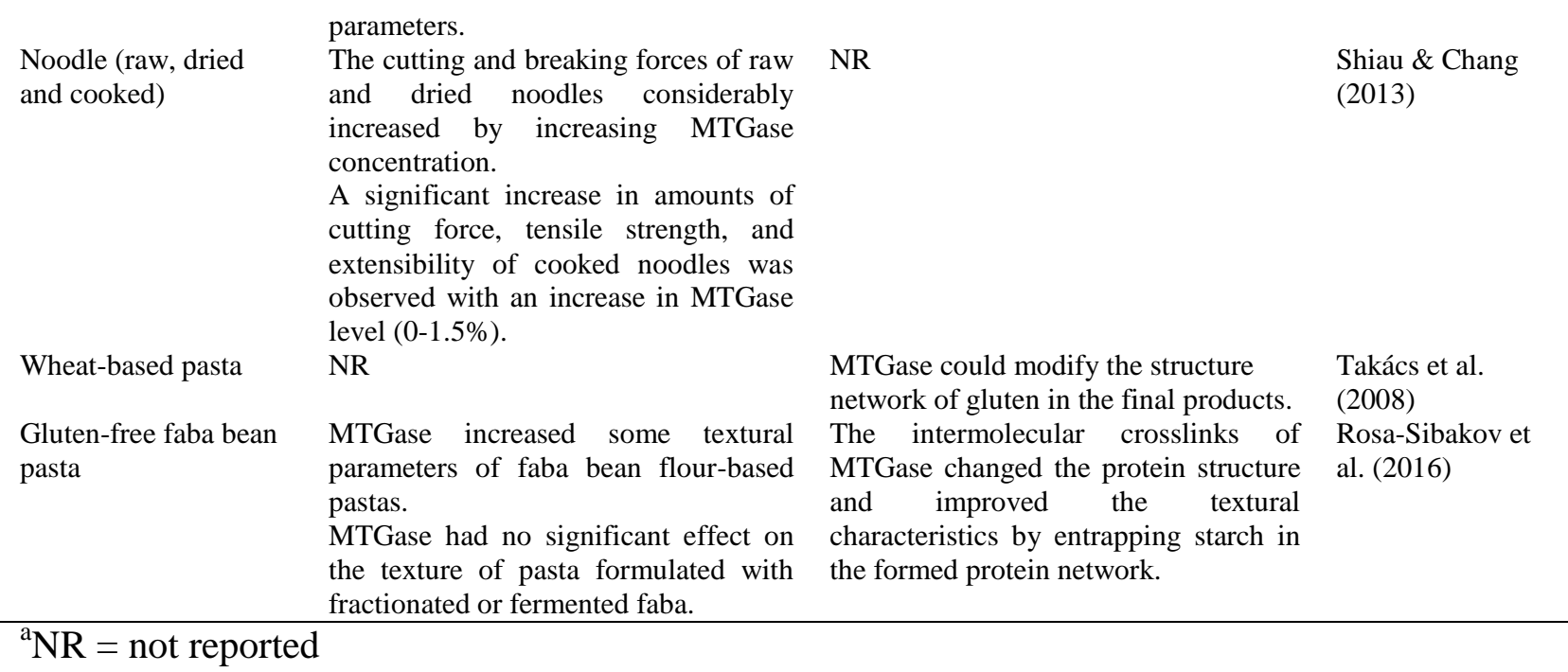

Table 4 continued

\begin{tabular}{|c|c|c|c|}
\hline $\begin{array}{l}\text { Noodles and } \\
\text { pasta products }\end{array}$ & Special mention of assessed textural properties & $\begin{array}{l}\text { Special mention of assessed } \\
\text { microstructural properties }\end{array}$ & References \\
\hline $\begin{array}{l}\text { Gluten-free } \\
\text { HPMC based } \\
\text { pasta }\end{array}$ & $\begin{array}{l}\text { The dough development time was increased, } \\
\text { while a decrease in degree of dough softening } \\
\text { was monitored. } \\
\text { The dough stability time and water absorption } \\
\text { were not significantly affected by MTGase. }\end{array}$ & NR & $\begin{array}{l}\text { Shokri et al. } \\
(2017)\end{array}$ \\
\hline Spaghetti & $\begin{array}{l}\text { A significant decrease in the solubility of } \\
\text { semolina dough proteins and a considerable } \\
\text { improvement in the final product were found by } \\
\text { the MTGase addition. }\end{array}$ & $\begin{array}{l}\text { The protein network in structure of } \\
\text { pasta supplemented with MTGase was } \\
\text { much tighter than that of the control. }\end{array}$ & $\begin{array}{l}\text { Aalami \& } \\
\text { Leelavathi } \\
(2008)\end{array}$ \\
\hline $\begin{array}{l}\text { Bran } \\
\text { supplemented } \\
\text { spaghetti }\end{array}$ & $\begin{array}{l}\text { Firmness values respectively increased and } \\
\text { decreased with increasing concentration of } \\
\text { MTGase and bran. }\end{array}$ & $\begin{array}{l}\text { MTGase-catalyzed crosslinking } \\
\text { strengthens the structural integrity of } \\
\text { spaghetti. }\end{array}$ & $\begin{array}{l}\text { Basman et al } \\
(2006)\end{array}$ \\
\hline $\begin{array}{l}\text { Fibre-enriched } \\
\text { spaghetti }\end{array}$ & $\begin{array}{l}\text { The MTGase addition increased dough maximal } \\
\text { resistance. } \\
0.5 \% \text { MTGase caused an optimum impact on } \\
\text { dough strength and produced the firmest and } \\
\text { least sticky pasta. }\end{array}$ & $\begin{array}{l}\text { More extensive cross-links and thicker } \\
\text { protein matrix were observed in the } \\
\text { MTGase supplemented pasta. }\end{array}$ & $\begin{array}{l}\text { Sissons et al. } \\
(2010)\end{array}$ \\
\hline
\end{tabular}




\begin{tabular}{|c|c|c|c|}
\hline $\begin{array}{l}\text { Noodles and } \\
\text { pasta products }\end{array}$ & Special mention of determined color properties & $\begin{array}{l}\text { Special mention of determined sensory } \\
\text { properties }\end{array}$ & References \\
\hline $\begin{array}{l}\text { Fresh SPI- } \\
\text { yellow alkaline } \\
\text { noodle }\end{array}$ & $\begin{array}{l}\text { SPI-MTGase noodle was significantly } \\
\text { evaluated with maximum } L^{*} \text { (brightness) value } \\
\text { among all the samples. }\end{array}$ & $\begin{array}{l}\text { MTGase-supplemented sample had the } \\
\text { highest hardness and springiness amounts. }\end{array}$ & $\begin{array}{l}\text { Yeoh et al. } \\
(2011)\end{array}$ \\
\hline $\begin{array}{l}\text { Canned SPI- } \\
\text { yellow alkaline } \\
\text { noodle }\end{array}$ & $\begin{array}{l}\text { The minimum yellowness was for SPI- } \\
\text { MTGase. } \\
\text { Retort processing led to an increase in } \mathrm{a}^{*} \\
\text { (redness), and a decrease in } \mathrm{b}^{*} \text { (yellowness) } \\
\text { levels. }\end{array}$ & $\mathrm{NR}^{\mathrm{a}}$ & $\begin{array}{l}\text { Yeoh et al. } \\
(2014)\end{array}$ \\
\hline $\begin{array}{l}\text { Yellow alkaline } \\
\text { noodles }\end{array}$ & $\begin{array}{l}\text { SPI/MTGase noodle revealed a lower } \mathrm{L}^{*} \text { value } \\
\text { than the control and SPI ones. }\end{array}$ & NR & $\begin{array}{l}\text { Foo et al. } \\
(2011)\end{array}$ \\
\hline $\begin{array}{l}\text { Yellow SPI- } \\
\text { noodle }\end{array}$ & $\begin{array}{l}\text { SPI-ribose-MTGase noodles showed a less L* } \\
\text { value compared with the control and SPI- } \\
\text { MTGase noodles. }\end{array}$ & NR & $\begin{array}{l}\text { Gan et al. } \\
(2009)\end{array}$ \\
\hline $\begin{array}{l}\text { Instant fried } \\
\text { noodle }\end{array}$ & $\begin{array}{l}\text { There was no noticeable difference in the color } \\
\text { between the different treatment blends. }\end{array}$ & NR & $\begin{array}{l}\text { Choy et al. } \\
(2010)\end{array}$ \\
\hline Rice noodle & $\begin{array}{l}\text { A marginal rise in } a^{*} \text { value of samples } \\
\text { incorporated with MTGase was obtained. }\end{array}$ & $\begin{array}{l}\text { Addition of MTGase in samples } \\
\text { formulated with xanthan gum led to a } \\
\text { marginally more scores for the surface, } \\
\text { chewing and mouthfeel after chewing } \\
\text { attributes. }\end{array}$ & $\begin{array}{l}\text { Yalcin \& } \\
\text { Basman } \\
(2008 \mathrm{a})\end{array}$ \\
\hline $\begin{array}{l}\text { Rice flour- } \\
\text { based noodle }\end{array}$ & NR & $\begin{array}{l}\text { The MTGase addition at } 7000 \mathrm{ppm} \text { to the } \\
\text { noodle dough promoted the sensory } \\
\text { scores. }\end{array}$ & $\begin{array}{l}\text { Shin et al. } \\
(2005)\end{array}$ \\
\hline Corn noodle & $\begin{array}{l}\text { The color values of } \mathrm{L}^{*}, \mathrm{a}^{*} \text { and } \mathrm{b} * \text { were slightly } \\
\text { changed by the formulation supplementation } \\
\text { with MTGase }\end{array}$ & $\begin{array}{l}\text { The MTGase-supplemented noodles } \\
\text { containing xanthan gum had higher } \\
\text { mouthfeel after chewing properties. }\end{array}$ & $\begin{array}{l}\text { Yalcin \& } \\
\text { Basman } \\
(2008 b)\end{array}$ \\
\hline $\begin{array}{l}\text { White salted } \\
\text { noodle }\end{array}$ & 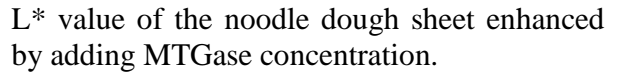 & NR & $\begin{array}{l}\text { Kang et al. } \\
(2014)\end{array}$ \\
\hline $\begin{array}{l}\text { Dried white } \\
\text { salted noodle }\end{array}$ & $\begin{array}{l}\text { A marginal adverse effect on the color was } \\
\text { resulted: } \\
\text { I. A significant decrease in } \mathrm{L}^{*} \text { value was found } \\
\text { by adding MTGase up to } 10 \mathrm{~g} / \mathrm{kg} \text {. II. A } \\
\text { significant increase in } \mathrm{b}^{*} \text { value was found with } \\
\text { the addition of MTGase }(1.0 \mathrm{~g} / \mathrm{kg}) \text {. }\end{array}$ & NR & $\begin{array}{l}\text { Wu \& Corke } \\
(2005)\end{array}$ \\
\hline $\begin{array}{l}\text { Whole-wheat } \\
\text { noodle }\end{array}$ & $\begin{array}{l}\text { MTGase increased the color quality of noodles } \\
\text { by inhibition discoloration reaction }\end{array}$ & $\begin{array}{l}\text { The enzyme promoted the sensory } \\
\text { characters of noodles (e.g., mouth-feel, } \\
\text { bite and springiness) }\end{array}$ & $\begin{array}{l}\text { Niu et al. } \\
(2017)\end{array}$ \\
\hline $\begin{array}{l}\text { Korean wheat } \\
\text { flour-based } \\
\text { noodle }\end{array}$ & NR & $\begin{array}{l}\text { An increase from } 3000 \text { to } 5000 \mathrm{ppm} \\
\text { MTGase led to an improvement in sensory } \\
\text { attributes. }\end{array}$ & $\begin{array}{l}\text { Seo et al. } \\
(2003)\end{array}$ \\
\hline $\begin{array}{l}\text { Milled lupin } \\
\text { flour/bran } \\
\text { based-noodle } \\
\text { Gluten-free pea } \\
\text { flour noodle }\end{array}$ & $\begin{array}{l}\text { The } L^{*}, a^{*} \text { and } b^{*} \text { values of lupin flour and } \\
\text { bran noodles were not changed by adding } \\
\text { MTGase. } \\
\mathrm{NR}^{\mathrm{a}}\end{array}$ & $\begin{array}{l}\text { Raw and cooked noodles supplemented } \\
\text { with MTGase with } 10 \% \text { lupin flour had } \\
\text { the maximum sensory scores } \\
\text { Application of } 140 \mathrm{mg} / \mathrm{kg} \text { MTGase in the } \\
\text { formulation resulted in the best sensory } \\
\text { and cooking attributes. }\end{array}$ & $\begin{array}{l}\text { Bilgiçli \& } \\
\text { İbanoğlu } \\
(2015) \\
\text { Takács et al. } \\
\text { (2007) }\end{array}$ \\
\hline $\begin{array}{l}\text { Capsaicin- } \\
\text { enriched } \\
\text { layered noodle }\end{array}$ & NR & $\begin{array}{l}\text { All the characters (appearance, } \\
\text { smoothness, odor, flavor and springiness) } \\
\text { had a sensory score more than } 5 \text {. } \\
\text { The preference decreased by increasing } \\
\text { MTGase level. }\end{array}$ & $\begin{array}{l}\text { Li et al. } \\
(2013)\end{array}$ \\
\hline
\end{tabular}




\section{ACCEPTED MANUSCRIPT}

Chili powderenriched layered noodle
The $\mathrm{L}^{*}$ and $\mathrm{b}^{*}$ values of the layered noodles were meaningfully lower than the commercial ones.

$\mathrm{a}^{*}$ value of all the prepared noodles was significantly more than the commercial ones.

Table 5 Effect of MTGase on the color and sensory attributes of different noodle and pasta types

${ }^{\mathrm{a}} \mathrm{NR}=$ not reported

\begin{tabular}{|c|c|c|c|}
\hline $\begin{array}{l}\text { Noodles and pasta } \\
\text { products }\end{array}$ & $\begin{array}{l}\text { Special mention of } \\
\text { determined color properties }\end{array}$ & Special mention of determined sensory properties & References \\
\hline $\begin{array}{l}\text { Moringa leaves } \\
\text { powder-enriched } \\
\text { noodle }\end{array}$ & $\begin{array}{l}\text { The color values }\left(\mathrm{L}^{*}, \mathrm{a}^{*}, \mathrm{~b}^{*}\right) \\
\text { were not affected by the } \\
\text { addition of MTGase. }\end{array}$ & $\begin{array}{l}\text { The maximum score of overall acceptability } \\
\text { belonged to noodles formulated with } 0.3 \% \\
\text { MTGase. }\end{array}$ & $\begin{array}{l}\text { Limroongreungrat et } \\
\text { al. (2011) }\end{array}$ \\
\hline Wheat-based pasta & $\mathrm{NR}^{\mathrm{a}}$ & $\begin{array}{l}\text { Evaluating the organoleptic attributes (appearance, } \\
\text { aroma, taste, consistency and weighted average) } \\
\text { showed a significant improvement in the noodle } \\
\text { quality with high water uptake and low cooking } \\
\text { loss. }\end{array}$ & Takács et al. (2008) \\
\hline $\begin{array}{l}\text { Pseudo-cereals } \\
\text { based pasta }\end{array}$ & $\mathrm{NR}^{\mathrm{a}}$ & $\begin{array}{l}\text { The MTGase addition improved sensory attributes } \\
\text { of pastas. }\end{array}$ & Kovács (2003) \\
\hline $\begin{array}{l}\text { Gluten-free faba } \\
\text { bean pasta }\end{array}$ & $\begin{array}{l}\text { MTGase addition decreased } \\
\text { the values of } \mathrm{L}^{*}, \mathrm{a}^{*} \text { and } \mathrm{b}^{*} \text {. } \\
\text { But these changes were not } \\
\text { observable. }\end{array}$ & $\begin{array}{l}\text { Fermentation process along with MTGase addition } \\
\text { increased hardness and particularly chewiness. }\end{array}$ & $\begin{array}{l}\text { Rosa-Sibakov et al. } \\
\text { (2016) }\end{array}$ \\
\hline $\begin{array}{l}\text { Gluten-free HPMC } \\
\text { based pasta }\end{array}$ & $\begin{array}{l}\text { MTGase addition had no } \\
\text { significant effect on the } \\
\text { pasta color. }\end{array}$ & $\begin{array}{l}\text { The pasta formulated with } 2 \% \text { HPMC and } 0.7 \% \\
\text { MTGase had the highest sensory scores for texture } \\
\text { and overall acceptability in comparison to the } \\
\text { control. }\end{array}$ & Shokri et al. (2017) \\
\hline Spaghetti & $\begin{array}{l}\text { The MTGase addition } \\
\text { significantly decreased } \mathrm{L}^{*}, \\
\mathrm{a}^{*} \text { and } \mathrm{b}^{*} \text { values of the } \\
\text { spaghetti surface. }\end{array}$ & NR & $\begin{array}{l}\text { Aalami \& } \\
\text { Leelavathi (2008) }\end{array}$ \\
\hline $\begin{array}{l}\text { Bran } \\
\text { supplemented } \\
\text { spaghetti }\end{array}$ & NR & $\begin{array}{l}\text { MTGase caused significantly higher sensory } \\
\text { scores for firmness, stickiness, and bulkiness } \\
\text { compared with the control samples. }\end{array}$ & Basman et al. (2006) \\
\hline $\begin{array}{l}\text { Fibre-enriched } \\
\text { spaghetti }\end{array}$ & $\begin{array}{l}\text { The } L^{*}, a^{*} \text { and } b^{*} \text { values } \\
\text { were not affected by } \\
\text { MTGase. }\end{array}$ & NR & Sissons et al. (2010) \\
\hline
\end{tabular}

Table 5 continued

${ }^{\mathrm{a}} \mathrm{NR}=$ not reported 